\title{
Snow Squalls: Forecasting and Hazard Mitigation
}

\author{
PETER C. BANACOS and ANDREW N. LOCONTO \\ NOAA/National Weather Service, Burlington, Vermont \\ GREGORY A. DEVOIR \\ NOAA/National Weather Service, State College, Pennsylvania \\ (Manuscript received 17 December 2013; review completed 19 February 2014)
}

\begin{abstract}
The rapid onset of blinding snowfall, strong winds, and falling temperatures associated with snow squalls can result in hazardous and potentially deadly road surface conditions. Transportation disruptions and threats to personal safety can be greatly disproportionate to the modest snowfall accumulations observed in such events, making snow squalls an important forecast and communicative challenge. To identify favorable synoptic and mesoscale snow squall environments, a 10-yr climatology of snow squalls producing surface visibility $\leq 0.8 \mathrm{~km}(0.5 \mathrm{mi})$ associated with upper troughs and cold fronts was constructed for three sites over northern New York and Vermont. A total of 36 snow squalls was identified, including 21 at Burlington, Vermont (KBTV). The median duration of heavy (moderate) snow with the squalls was 17 (26) min, and-for the events affecting KBTV - the median snow accumulation was only $2.5 \mathrm{~cm}(1.0 \mathrm{in})$.

A composite study based on these 36 events was performed using North American Regional Reanalysis data and a control dataset for winter 2005-06. All identified snow squall events occurred on the cyclonicshear side of a mid- to upper-tropospheric jet streak and within deep-layer cyclonically curved flow. Surfacebased instability [median convective available potential energy (CAPE) $<50 \mathrm{~J} \mathrm{~kg}^{-1}$ ], high relative humidity in the 0-2-km AGL layer, frontogenetic forcing, and strong surface isallobaric (rise/fall) couplets often were found with the snow squalls. The isallobaric wind was found to add constructively to the background gradient flow, and when combined with steep near-surface lapse rates, acted to produce the squall conditions. The presence of CAPE was the best discriminator between the snow squall cases and the control. As a result of their convective nature, snow squalls were observed most often during the daylight hours, with $69 \%$ of the events occurring between 1300 and 2300 UTC. Results from the composite study were used to formulate a 4panel visualization display and a multivariate, non-dimensional snow squall parameter. Case examples are shown to demonstrate the utility of these forecasting aids. Strategies for mitigation of snow squalls as a transportation hazard also are discussed.
\end{abstract}

\section{Introduction}

Mesoscale convective systems (MCSs) producing short-lived heavy snow, a sudden increase in wind speed, and decreasing temperatures (Fig. 1) typically are referred to as snow squalls or-to differentiate from lake-effect squalls-snow "bursts" (Pettegrew et al. 2009; Milrad et al. 2011). Snow squalls observed near cold fronts fit into a class of events called "high impact, sub-advisory" (HISA; DeVoir and Ondrejik 2008) in that they typically do not reach National Weather Service (NWS) criteria for an official winter weather advisory or warning product. Yet, such events can result in loss of life and damage due to vehicular crashes (DeVoir and Ondrejik 2008; Table 1), especially during high-traffic/rush-hour periods (e.g., highway "pile-ups"). These transportation impacts stem largely from the very low visibility in heavy snow, slippery or icy road conditions, and driver anxiety and confusion due to rapidly deteriorating weather and road conditions (DeVoir 2004). Without a forecast of significant snow accumulation, casual recipients of forecasts calling for "scattered snow showers," for example, have little reason to postpone travel and often have no advance warning of potentially severe visibility and road impacts from brief blizzard-like 


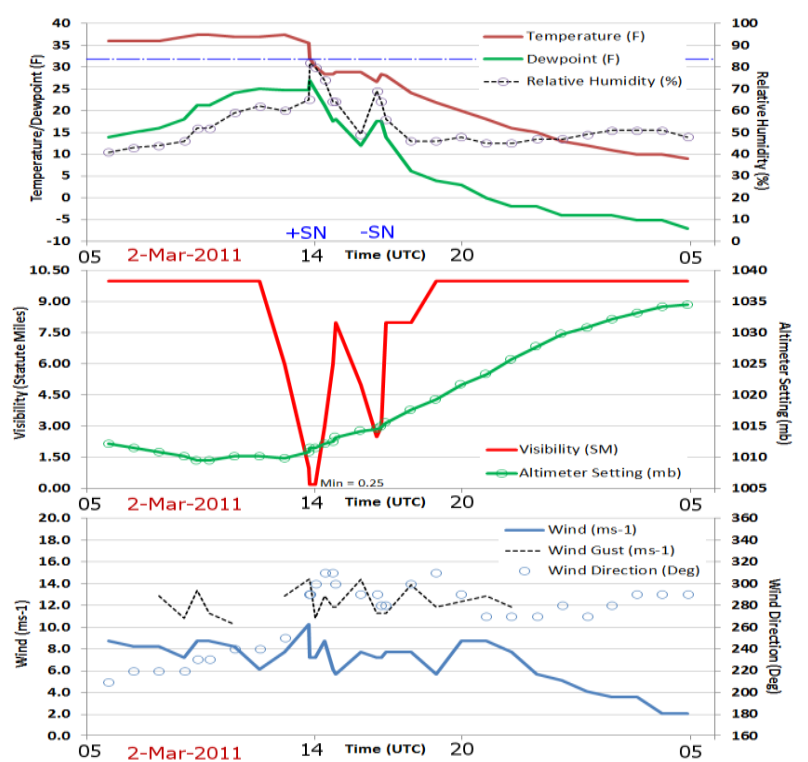

Figure 1. Meteogram showing frontal passage with snow squall conditions at Massena, NY (KMSS), on 2 March 2011. The frontal passage occurred just before 1400 UTC. Heavy snow was observed from 1353 until 1428 UTC. The blue dashed-dot line in the top panel denotes $0^{\circ} \mathrm{C}\left(32^{\circ} \mathrm{F}\right)$. Click image for an external version; this applies to all figures hereafter. conditions. The rapid onset of adverse weather conditions in a snow squall makes driver adaptation (i.e., reduced speed and increased braking distance) difficult. A lack of preparation for the exceedingly quick deterioration of conditions in a snow squall suggests that societal impacts mimic the first snowfall of the season, in which significantly higher numbers of fatal crashes have been reported compared to travel on other snowy days (Eisenberg and Warner 2005).

Negative impacts to transportation also can be experienced for hours following snow squalls in socalled "flash freeze" situations, in which falling snow that initially melts on untreated, warm surfaces creates a layer of ice as road surface temperatures abruptly decrease following the coincident passage of the cold front. To mitigate societal impact, further work is needed both in accurately forecasting and effectively communicating snow squall events such that (1) travelers are better informed about, and might avoid, the most hazardous time periods and (2) road crews can effectively pretreat pavement to limit the potential for ice.

Table 1. A sample of known high-impact, sub-advisory (HISA) events related to snow squalls across the Great Lakes, northeastern United States, and southeastern Canada.

\begin{tabular}{|c|c|c|c|c|}
\hline Date & Time (LST) & $\begin{array}{l}\text { State/ } \\
\text { Province }\end{array}$ & Character & Transportation Impacts \\
\hline 12 Mar 1998 & 1235 & MA, NH & Snow squalls & $\begin{array}{l}\text { Fatal 30-35 vehicle pileup on I-495 near Rt2 (Boxboro, } \\
\text { MA); two fatalities including 3-month-old girl. }\end{array}$ \\
\hline 12 Feb 1999 & 0900 & WI & $\begin{array}{l}\text { Snow squalls (1 day after record } \\
\text { warmth) }\end{array}$ & $\begin{array}{l}\text { Pileups involving } 80 \text { cars on } 2 \text { freeways - near Menomonee } \\
\text { Falls, WI (18 injured). }\end{array}$ \\
\hline 28 Dec 2001 & 1600 & PA & Snow squalls & $\begin{array}{l}\text { I-80 pileups near Loganton ( } 8 \text { dead, } 45 \text { injured) - more than } \\
100 \text { vehicles; I-81 pileups near Hazleton, PA (1 fatality). }\end{array}$ \\
\hline 2 Dec 2003 & 0600 & MA & Snow squalls & $\begin{array}{l}\text { Boston metro area with } 500+\text { accidents; widespread, } \\
\text { multiple-hour traffic delays. }\end{array}$ \\
\hline 6 Jan 2004 & 1215 & PA & Snow squalls & $\begin{array}{l}\text { Fatal I-80 pileups (6 dead, } 17 \text { injured); highway closed } 2 \\
\text { days. }\end{array}$ \\
\hline 12 Feb 2006 & 1130 & MI & Snow squalls & 86 vehicle chain reaction pileup on US 3 ( 25 injured). \\
\hline 26 Feb 2006 & 0920 & PA & Snow squalls & $\begin{array}{l}25 \text { accidents over a quarter-mile stretch of I-81; highway } \\
\text { closed for } 5 \mathrm{~h} \text {. }\end{array}$ \\
\hline 7 Dec 2006 & 1535 & PA & Snow squalls & $\begin{array}{l}\text { 15-vehicle pileup; no injuries/fatalities despite conditions } \\
\text { similar to } 6 \text { Jan } 2004 .\end{array}$ \\
\hline 16 Jan 2008 & 1045 & WV & Snow squalls & Numerous accidents; 8 -vehicle pileup on I-81 (2 fatalities). \\
\hline 20 Jan 2008 & 1300 & ON & Snow squalls & $\begin{array}{l}100 \text { vehicles involved in several pileups ( } 1 \text { dead, } 29 \text { injured); } \\
\text { highway closure. }\end{array}$ \\
\hline 10 Feb 2008 & 1230 & NY & Blowing snow/whiteout & $\begin{array}{l}1 \text { dead and } 24 \text { injured in I-390 pileup near Rochester, NY; } \\
37 \text {-mph gusts created near-zero visibility. }\end{array}$ \\
\hline 10 Feb 2008 & 1400 & PA & Snow squalls & $\begin{array}{l}\text { 68-car pileup on I-81 (1 dead and } 36 \text { injured); highway } \\
\text { closure. }\end{array}$ \\
\hline 8 Jan 2009 & 0819 & WV & Snow squalls & $\begin{array}{l}9 \text { separate wrecks, one involving } 16 \text { vehicles (6 tractor } \\
\text { trailers); } 15 \text { injuries; highway closure. }\end{array}$ \\
\hline 2 Jan 2012 & $1000-1600$ & $\begin{array}{l}\text { OH, KY, } \\
\text { PA, MD,VA }\end{array}$ & Snow squalls/flash freezes & $\begin{array}{l}\text { Numerous multi-vehicle pileups on I-75 (OH, KY), I-80 } \\
\text { (PA), I-70 (MD), and I-81 (VA); dozens injured. }\end{array}$ \\
\hline 31 Jan 2013 & 0900-1030 & $\begin{array}{l}\text { PA, OH, MI, } \\
\text { IN }\end{array}$ & Snow squalls & $\begin{array}{l}\text { Multi-vehicle pileups on I-80 (PA), I-75 (MI; } 3 \text { fatalities, } 20 \\
\text { injuries), and I-70 (IN; } 1 \text { fatality, } 10 \text { injuries); highway } \\
\text { closures. }\end{array}$ \\
\hline
\end{tabular}


Research on non-lake-effect snow squalls has primarily focused on case studies. An unusually intense and long-lived line of snow squalls with surface wind gusts in excess of $25.7 \mathrm{~m} \mathrm{~s}^{-1}(50 \mathrm{kt})$ and cloud-toground lightning affecting an area from the eastern Dakotas through the upper Mississippi Valley to the southern Great Lakes on 11-12 February 2003 was documented by Pettegrew et al. (2009). This event occurred on the cyclonic shear side of a $69-\mathrm{m} \mathrm{s}^{-1}$ (135 $\mathrm{kt}$ ) 300-hPa jet and with an associated mid-tropospheric short-wave trough. At the surface, the snow squalls were organized along a cold front having low-level frontogenetic forcing and $50-\mathrm{hPa}$ mean mixed-layer convective available potential energy (CAPE) values around $100 \mathrm{~J} \mathrm{~kg}^{-1}$. The convective line differed from warm-season squall lines in terms of having lower radar reflectivity (only 40-45 dBZ at no higher than $3.7 \mathrm{~km}$ AGL). Likewise, there was no identified rearinflow jet or trailing stratiform precipitation region (Pettegrew et al. 2009). Separate studies noted that the 11-12 February 2003 event resembled the composite for strongly forced wind-producing MCSs in limited moisture environments (so-called low-dewpoint derechos; Corfidi et al. 2006) or strongly forced, lowinstability cold fronts (van den Broeke et al. 2005) except with a vertical temperature structure supportive of snow (Corfidi et al. 2006). In the absence of a convective cold pool developed through evaporative effects, strong winds could be the result of dynamically induced large isallobaric wind effects, as might occur within an intense isallobaric gradient along a front or as part of a thermally direct frontogenetic circulation.

Milrad et al. (2011) diagnosed a snow "burst" event over eastern Ontario and western Quebec on 28 January 2010. Similarly, this study concluded that quasi-geostrophic forcing, low-level frontogenesis along an arctic front, and a markedly unstable environment (with steep 925-700-hPa lapse rates of 8-9 ${ }^{\circ} \mathrm{C} \mathrm{km}^{-1}$ ) produced organized convection "rooted in the near-surface boundary layer." Moreover, the authors documented a moist absolute unstable layer (MAUL; Bryan and Fritsch 2000) associated with the moist convection and large values of mesoscale ascent in the snow squall environment. The authors noted that "a climatology of similar and null events would allow diagnostics to determine what tools an operational forecaster can use to better assess the occurrence" of similar events on the "short- and medium-range time scales."
The only previous study of snow squalls taking a composite approach was that of Lundstedt (1993), which was geared toward creation of a snow squall forecasting technique. In his development of the Wintertime Instability Index (WINDEX) forecast nomogram (his Fig. 3), nearly 90 cold-frontal passages over northern New England were used to establish relationships between Nested Grid Model values of moisture, instability (lapse rate), and lift (derived from the 12-h lifted index change before and after frontal passage) with observed weather at Concord, New Hampshire. Lundstedt calibrated WINDEX for $<4.8$ $\mathrm{km}(3 \mathrm{mi})$ visibility in snow, a criterion corresponding to instrument flight rules with recognition of snow squalls as an aviation hazard. While the WINDEX technique has been used with some success in the northeastern United States, it is based on tabular model output at a limited number of stations and was formulated from a numerical model no longer run operationally. A modern, graphical composite parameter for forecasting snow squalls is developed in this paper-in a method similar to what has been done for other types of moist convection including the significant tornado and supercell composite parameters (Thompson et al. 2003, 2004) and derecho composite parameter (Evans and Doswell 2001).

This paper examines snow squalls with several goals: (1) establish a better understanding of associated environmental conditions on the mesoscale and synoptic scale, (2) develop a forecast approach and composite snow squall parameter (SNSQ) to aid in prediction and enhanced situational awareness, and (3) discuss the adverse effects on road transportation and preliminary NWS efforts to mitigate those adverse effects. The goal of societal mitigation is aligned with NWS impact-based decision support services (IDSS; NWS 2013), which aims to inform officials of critical weather conditions that have specific adverse impacts on public safety and the activities of the general public.

This paper is organized as follows. Section 2 describes data and methods used in constructing the synoptic climatology of snow squalls. In section 3, results are presented showing surface characteristics and synoptic and mesoscale environmental structures of snow squalls. Section 4 discusses snow squall forecasting and the SNSQ. Section 5 presents three case examples. Section 6 offers a concluding discussion, including how forecasting and communicating the threat associated with snow squalls can be improved to lessen negative transportation impacts. 


\section{Data and methods}

Surface data (Meteorological Aerodrome Report, or METAR) archives from the National Climatic Data Center were searched over 10 cool seasons (2001-02 through 2010-11) at Burlington (KBTV) and Montpelier (KMPV), Vermont, and Massena, New York (KMSS) (Fig. 2), for the occurrence of snow squalls. No formal definition currently exists for what constitutes a snow squall (e.g., by either the American Meteorological Society or World Meteorological Organization). The publication Surface Weather Observations and Reports (FMH-1; OFCM 2005) states that a squall is "A strong wind characterized by a sudden onset in which the wind speed increases at least 16 knots and is sustained at 22 knot or more for at least one minute." It became apparent early on that the FMH-1 criteria rarely were achieved in the Burlington, Vermont, NWS Weather Forecast Office (WFO) area of responsibility, including for known events having road transportation impact in terms of crashes and significant traffic delays that were central to the goals of the study. We chose to identify occurrences of moderate or heavy snow [surface visibility $\leq 0.8 \mathrm{~km}$ $(0.5 \mathrm{mi})]$ accompanied by any increase in wind speed within a period of $1 \mathrm{~h}$ leading up to and including the onset of visibility $\leq 0.8 \mathrm{~km}$, and a wind direction from 190 to 360 degrees. The wind direction criterion was applied simply to reduce the dataset to a reasonable size and remove most moderate or heavy snow observations in association with Nor' easters.

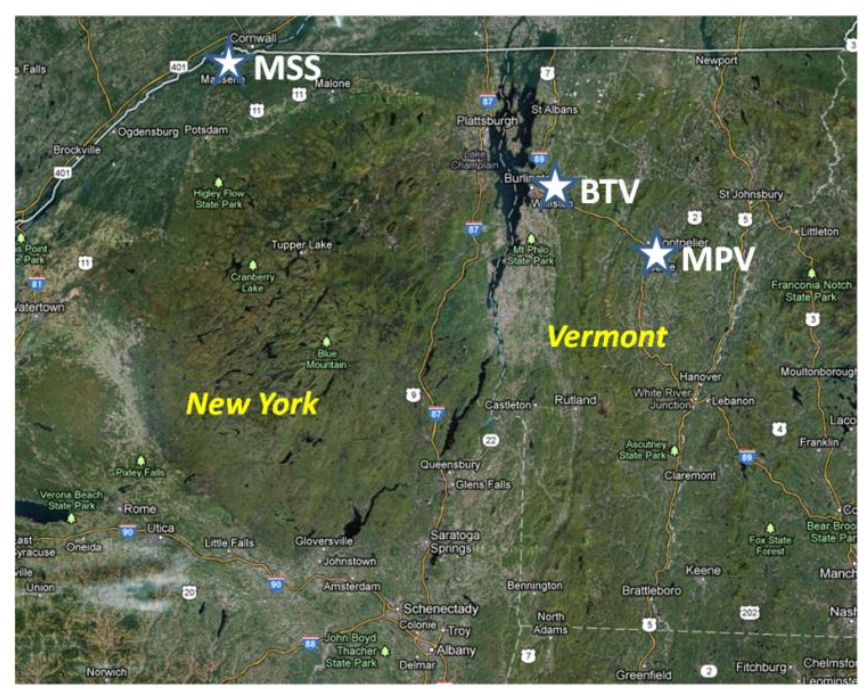

Figure 2. Regional map across NY and VT showing the locations of three ASOS stations used in developing the snow squall database for this study [Massena, NY (KMSS); Burlington, VT (KBTV); and Montpelier, VT (KMPV)].
Each prospective observation (hourlies and/or specials) was compared with 2-km radar composite reflectivity archives to manually determine if the snow was associated with one or more narrow convective bands (as would occur with a mobile cold front and/or shortwave trough), and not from a stratiform or broader low-level warm-air advection setup. This method resulted in 36 unique snow squall events, six of which were "hybrid" events where preexisting bands of lakeeffect precipitation interacted with a cold front (Fig. 3 ). From the surface data archive, the timing, duration, peak winds, temperatures, lowest visibility, and characteristics of the upper flow were logged (Table 2). A contracted surface observer augmented the Automated Surface Observation System (ASOS) reports at KBTV, and so hourly changes in snowboard measurement and snow water equivalent also were logged for the 21 identified events occurring at KBTV.

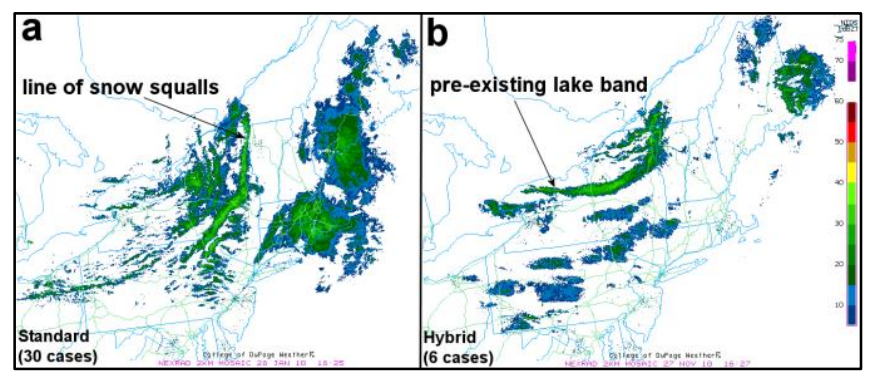

Figure 3. The 2-km radar mosaic composite reflectivity (dBZ) for a representative (a) standard snow squall case and (b) hybrid case with a preexisting lake-effect snowband.

With snow squall dates and times recorded, hourly North American Mesoscale (NAM) model soundings and time-height cross sections were examined for representative kinematic and thermodynamic patterns using BUFKIT (Mahoney and Niziol 1997). For synoptic-scale surface and upper-air conditions, daily composite means and climatological departures from the 36-case sample were analyzed using the North American Regional Reanalysis (NARR; Mesinger et al. 2006). NARR grid files also were used to spatially examine fields associated with each event using the General Meteorological Package (GEMPAK, version 5.11.1; desJardins et al. 1991).

A host of kinematic, thermodynamic, and moisture variables was assessed using a bilinear interpolation from the gridded NARR to the ASOS location for the nearest NARR time to the snow squall start time. Variables also were examined for a control dataset composed of all of the 3-h NARR time steps from 1 November 2005 through 31 March 2006, minus the 
Table 2. Listing of 36 snow squall events used in the composite study. "Min VSBY" indicates minimum observed visibility in km (mi). Start time refers to the time of first moderate snow report. PK WND references the maximum observed gust, with coincident sustained wind speed and direction (kt; multiply by 0.5144 for $\mathrm{m} \mathrm{s}^{-1}$ ). "Start Temp" and "End Temp" refer to the observed temperature immediately prior to the first moderate snow report and the ending temperature two hours after the starting time, respectively. Case dates labeled with an asterisk are "hybrid" cases, as described in Fig. 3.

\begin{tabular}{|c|c|c|c|c|c|c|c|c|}
\hline DATE & ASOS & $\begin{array}{l}\text { Min VSBY } \\
\text { km (mi) }\end{array}$ & $\begin{array}{l}\text { Start Time } \\
\text { (UTC) }\end{array}$ & $\begin{array}{l}\text { VSBY <0.4 } \\
\text { km }(0.25 \mathrm{mi}) \\
(\mathrm{min})\end{array}$ & $\begin{array}{l}\text { VSBY }<0.8 \\
\text { km }(0.5 \text { mi) } \\
(\min )\end{array}$ & $\begin{array}{l}\text { PK WND } \\
\text { (within 1h of } \\
\text { Min VSBY) } \\
\end{array}$ & $\begin{array}{l}\text { Start Temp } \\
\left({ }^{\circ} \mathbf{C}\right)\end{array}$ & $\begin{array}{l}\text { End temp } \\
\left({ }^{\circ} \mathbf{C}\right)\end{array}$ \\
\hline$* 3 / 23 / 2002$ & KBTV & $0.4(0.25)$ & 2211 & 35 & 48 & $27013 \mathrm{G} 19 \mathrm{KT}$ & 0 & -0.6 \\
\hline $1 / 13 / 2003$ & KMSS & $0.4(0.25)$ & 1653 & 14 & 38 & $22021 \mathrm{G} 24 \mathrm{KT}$ & -5 & -3.9 \\
\hline *2/9/2003 & KMPV & $0.4(0.25)$ & 2100 & 14 & 26 & $31011 \mathrm{G} 18 \mathrm{KT}$ & -7.2 & -7.8 \\
\hline $12 / 2 / 2003$ & KMPV & $0.4(0.25)$ & 1551 & 19 & 28 & 31013G17KT & -7.8 & -9.4 \\
\hline $3 / 15 / 2004$ & KMSS & $0.4(0.25)$ & 744 & 9 & 9 & 26020G32KT & 1.7 & 1.1 \\
\hline $3 / 23 / 2004$ & KBTV & $0.4(0.25)$ & 2340 & 38 & 45 & $30011 \mathrm{G} 23 \mathrm{KT}$ & 0.6 & -1.1 \\
\hline $12 / 3 / 2004$ & KBTV & $0.4(0.25)$ & 2200 & 14 & 20 & $35010 \mathrm{KT}$ & -4.4 & -6.1 \\
\hline $12 / 17 / 2004$ & KMPV & $0.4(0.25)$ & 1442 & 20 & 20 & $30021 \mathrm{G} 29 \mathrm{KT}$ & 0 & -3.3 \\
\hline $1 / 11 / 2005$ & KBTV & $0.8(0.5)$ & 124 & N/A & 3 & $29013 \mathrm{G} 25 \mathrm{KT}$ & 1.1 & -1.1 \\
\hline $2 / 13 / 2005$ & KBTV & $0.4(0.25)$ & 924 & 17 & 89 & $34017 \mathrm{G} 21 \mathrm{KT}$ & -4.4 & -6.7 \\
\hline $2 / 20 / 2005$ & KBTV & $0.8(0.5)$ & 311 & N/A & 13 & $34011 \mathrm{G} 19 \mathrm{KT}$ & -7.2 & -7.8 \\
\hline $11 / 24 / 2005$ & KBTV & $0.8(0.5)$ & 2341 & N/A & 13 & $27015 \mathrm{G} 21 \mathrm{KT}$ & -1.1 & -2.2 \\
\hline $12 / 20 / 2005$ & KBTV & $0.8(0.5)$ & 2222 & N/A & 11 & $32012 \mathrm{G} 19 \mathrm{KT}$ & -3.3 & -5 \\
\hline *2/7/2006 & KMPV & $0.4(0.25)$ & 447 & 4 & 44 & $32010 \mathrm{G} 16 \mathrm{KT}$ & -3.9 & -6.7 \\
\hline $2 / 24 / 2006$ & KBTV & $0.21(0.13)$ & 1510 & 47 & 64 & $31019 \mathrm{G} 31 \mathrm{KT}$ & -3.9 & -5 \\
\hline $3 / 1 / 2006$ & KBTV & $0.8(0.5)$ & 309 & N/A & 10 & $33015 \mathrm{G} 23 \mathrm{KT}$ & -9.4 & -11.7 \\
\hline $3 / 15 / 2006$ & KMPV & $0.4(0.25)$ & 624 & 7 & 13 & 29016G21KT & -0.6 & -2.2 \\
\hline $3 / 19 / 2006$ & KMPV & $0.4(0.25)$ & 1414 & 24 & 24 & 29013G17KT & -7.2 & -6.7 \\
\hline $1 / 10 / 2007$ & KBTV & $0.4(0.25)$ & 1410 & 12 & 35 & $33015 \mathrm{G} 20 \mathrm{KT}$ & -5.6 & -10.6 \\
\hline $1 / 24 / 2007$ & KMPV & $0.4(0.25)$ & 1348 & 10 & 15 & $31011 \mathrm{G} 16 \mathrm{KT}$ & -7.2 & -5.6 \\
\hline$* 2 / 5 / 2007$ & KMPV & $0.4(0.25)$ & 1534 & 17 & 70 & $31014 \mathrm{G} 21 \mathrm{KT}$ & -16.7 & -17.2 \\
\hline 2/9/2007 & KBTV & $0.8(0.5)$ & 728 & N/A & 26 & $34018 \mathrm{G} 23 \mathrm{KT}$ & -8.3 & -11.1 \\
\hline $3 / 5 / 2007$ & KMPV & $0.4(0.25)$ & 1742 & 21 & 31 & 30018G30KT & -2.8 & -3.9 \\
\hline $11 / 30 / 2007$ & KMSS & $0.4(0.25)$ & 2128 & 15 & 20 & $21016 \mathrm{G} 25 \mathrm{KT}$ & 0.6 & 0 \\
\hline $12 / 8 / 2007$ & KBTV & $0.4(0.25)$ & 1721 & 14 & 25 & $32020 \mathrm{G} 29 \mathrm{KT}$ & 2.8 & 0 \\
\hline $1 / 20 / 2008$ & KBTV & $0.4(0.25)$ & 612 & 8 & 11 & 34019G26KT & -6.7 & -10 \\
\hline $2 / 10 / 2008$ & KBTV & $0.4(0.25)$ & 1629 & 22 & 35 & $33013 \mathrm{KT}$ & 0.6 & 0 \\
\hline $2 / 15 / 2008$ & KMPV & $0.4(0.25)$ & 2012 & 26 & 26 & $32014 \mathrm{G} 24 \mathrm{KT}$ & -1.1 & -5.6 \\
\hline $12 / 7 / 2008$ & KBTV & $0.4(0.25)$ & 2038 & 16 & 22 & 30019G26KT & -1.7 & -5.6 \\
\hline$* 1 / 25 / 2009$ & KBTV & $0.4(0.25)$ & 2054 & 18 & 48 & 36010G18KT & -10 & -11.7 \\
\hline $1 / 30 / 2009$ & KBTV & $0.4(0.25)$ & 2242 & 29 & 39 & 27006G16KT & -1.7 & -4.4 \\
\hline $12 / 29 / 2009$ & KBTV & $0.4(0.25)$ & 818 & 25 & 25 & 32018G30KT & -2.8 & -11.1 \\
\hline $1 / 28 / 2010$ & KBTV & $0.21(0.13)$ & 1918 & 14 & 29 & 28012G20KT & 0 & -2.2 \\
\hline *11/27/2010 & KBTV & $0.21(0.13)$ & 1707 & 15 & 23 & 30013G31KT & 0 & 0.6 \\
\hline $2 / 19 / 2011$ & KMPV & $0.4(0.25)$ & 549 & 11 & 11 & 29027G37KT & 3.9 & 0 \\
\hline $3 / 2 / 2011$ & KMSS & $0.4(0.25)$ & 1355 & 30 & 30 & $29020 \mathrm{G} 28 \mathrm{KT}$ & 2.8 & -1.7 \\
\hline
\end{tabular}


seven snow squall time steps from that winter (a total of 1201 grids). Differences between the snow squall and control datasets emerged for some variables, allowing us to develop forecasting aids including a 4panel visualization and a non-dimensional SNSQ, which are discussed in sections 4 and 5 .

\section{Results}

\section{a. Surface environment}

Snow squall occurrence at the three analyzed ASOS sites in the WFO Burlington area of responsibility were found across five months (NovemberMarch) with a peak of 10 events in February (Fig. 4a). Events were most common between 1300 and 2300 UTC ( 25 cases) and less frequent during the overnight hours (11 cases between 0100 and 0900 UTC; Fig. 4b). Despite low sun angles during the winter months, the occurrence of surface-based instability is greater during the daylight hours and likely plays a role in the observed diurnal variation. Also, visibility is higher at night for the same intensity snowfall owing to different coefficient of extinction measurements by ASOS (Rasmussen et al. 1999). This instrumentation effect may have contributed to the smaller number of snow squall events meeting the $\leq 0.8 \mathrm{~km}(0.5 \mathrm{mi})$ visibility criterion at night.

Consistent with our personal experiences, snow squalls are intense but brief events with the duration of continuous heavy snow [(ASOS visibility $\leq 0.4 \mathrm{~km}$ $(0.25 \mathrm{mi})]$ for the middle $50 \%$ of events lasting 14-23 min, and the longest event lasting $47 \mathrm{~min}$ (Fig. 5). The period of continuous snow with visibility $\leq 0.8 \mathrm{~km}$ (0.50 mi) lasted $15-38 \mathrm{~min}$ for the middle $50 \%$ of cases (Fig. 5). An analysis of the 21 cases at KBTV shows that the median amount of snow produced with a snow squall is $2.54 \mathrm{~cm}$ ( 1 in), with an interquartile range of $1.0-5.1 \mathrm{~cm}(0.4-2 \mathrm{in}$; Fig. 6a). For the highest inclusive 12-h period, snowfall amounts had a median value of only $4.1 \mathrm{~cm}$ (1.6 in), suggesting the majority of the snow occurs during the period of the snow squall, with only one case exceeding the local winter weather advisory criteria of $10.2 \mathrm{~cm}$ (4 in) in $12 \mathrm{~h}$. This confirms the "sub-advisory" nature of snow squall events. The median snow-water equivalent produced with the squalls is just $0.13 \mathrm{~cm}(0.05 \mathrm{in}$; Fig. $6 \mathrm{~b}$ ), not an amount that would typically be viewed as significant. The snow-to-liquid ratio associated with these events is relatively large: $17: 1$ to $31: 1$ for the interquartile range (Fig. 6c). These relatively high snow-to-liquid ratios likely are a function of limited-

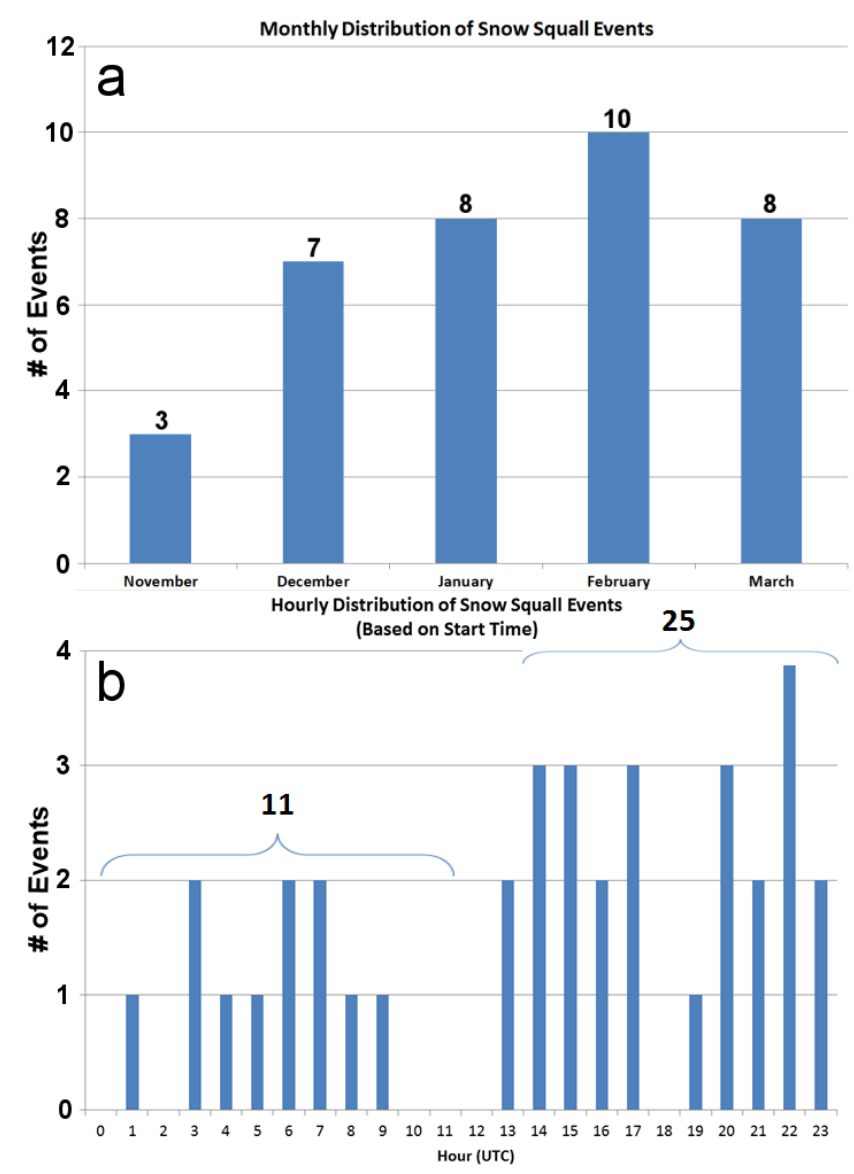

Figure 4. Temporal distribution of 36 snow squall events collected at three ASOS sites over northern NY and VT from 2002 through 2011: (a) Monthly distribution and (b) hourly distribution of snow squall events (based on start time of event).

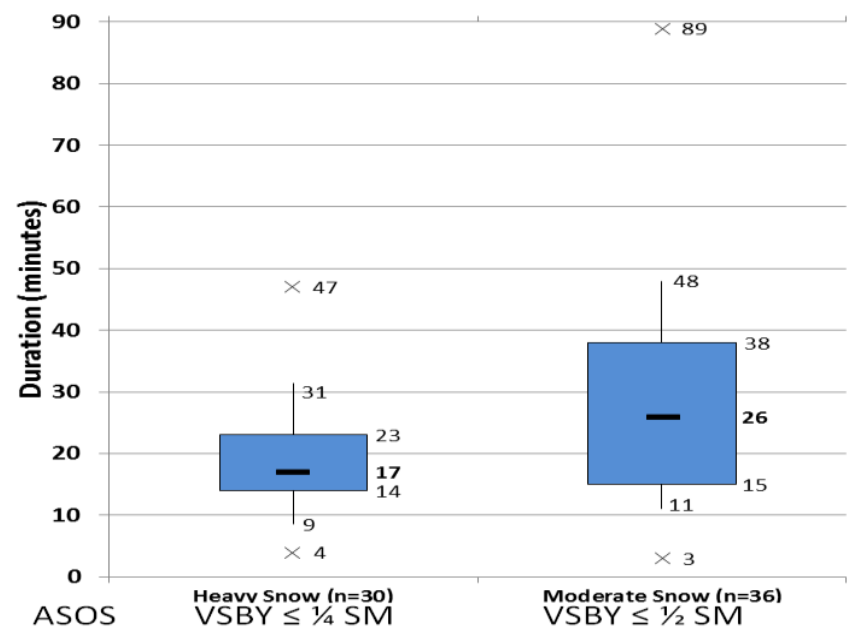

Figure 5. Box-and-whiskers plot showing the duration of moderate and heavy snow (min) for 36 snow squall events across NY and VT as reported by ASOS. Solid bar represents median value, filled box shows the interquartile range (from the 25 th to 75 th percentile), and the ends of the whiskers correspond to the 10th and 90th percentile values. The " $x$ " represents extreme values in the dataset. Thirty of the 36 events had observed heavy snow, as denoted by $n$. 

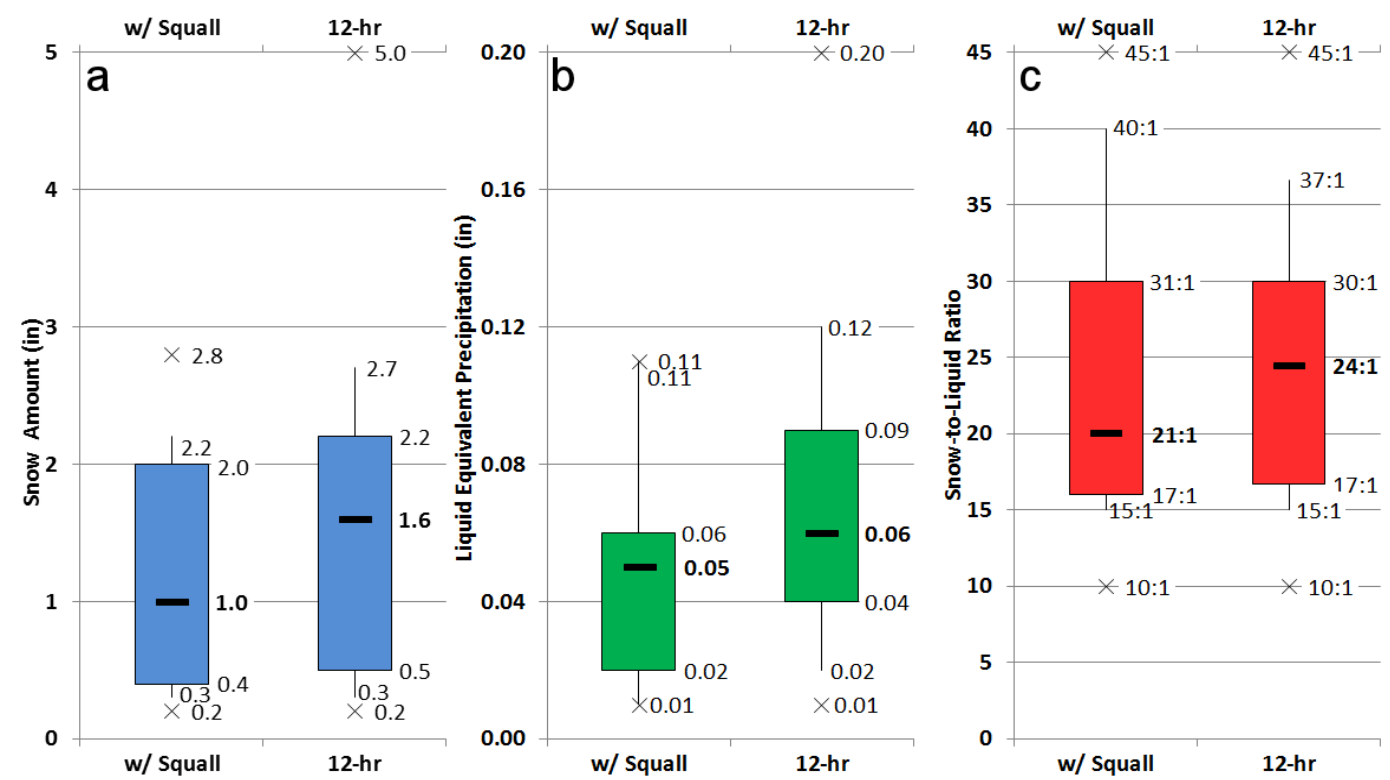

Figure 6. As in Fig. 5 except the subset of 21 cases occurring at Burlington, VT, for (a) snow amount, (b) liquid equivalent precipitation, and (c) snow-to-liquid ratio. The left box-and-whiskers graphic shows the value during the hour(s) containing the squall, and the right graph shows the highest value for the 12-h period including the hour the snow squall occurred.

moisture continental westerly flow that combined with optimized deposition microphysics and saturated conditions in the dendrite growth zone $\left(-12\right.$ to $\left.-18^{\circ} \mathrm{C}\right)$, which will be shown later.

The median peak sustained wind speed and wind gust within $2 \mathrm{~h}$ of squall occurrence for all 36 cases was $9 \mathrm{~m} \mathrm{~s}^{-1}(18 \mathrm{kt})$ and $12.5 \mathrm{~m} \mathrm{~s}^{-1}(25 \mathrm{kt})$, respectively (Fig. 7a). The average increase in wind speed associated with the squall onset was $3.6 \mathrm{~m} \mathrm{~s}^{-1}(7 \mathrm{kt})$, with a maximum of $9.3 \mathrm{~m} \mathrm{~s}^{-1}(18 \mathrm{kt})$ and a minimum of $1.0 \mathrm{~m}$ $\mathrm{s}^{-1}(2 \mathrm{kt})$. Peak wind gusts during the squalls ranged from 18.2 to $19.0 \mathrm{~m} \mathrm{~s}^{-1}$ (16 to $37 \mathrm{kt}$ ). That these squalls are often associated with cold fronts is evident in the decrease in temperature and low-level drying that occurs in the 2-m data following the squall passage (Fig. 7b); the median decrease in temperature was $2.3^{\circ} \mathrm{C}\left(4.2^{\circ} \mathrm{F}\right)$ and the median decrease in dewpoint was $3.7^{\circ} \mathrm{C}\left(6.6^{\circ} \mathrm{F}\right)$ at $3 \mathrm{~h}$ after snow squall passage. Twelve of the cases began with 2-m temperatures $\geq 0^{\circ} \mathrm{C}$. Median sea-level pressure rises of $2.5 \mathrm{hPa}(3.7$ $\mathrm{hPa})$ over $2 \mathrm{~h}(3 \mathrm{~h})$ are evident following squall occurrence (Fig. 7c), consistent with passage of a cold front.

\section{b. Tropospheric environment}

An examination of the NARR composite fields shows that the upper-tropospheric flow is cyclonically curved in the mean, with the study area on the cyclonic shear side of a $50-55 \mathrm{~m} \mathrm{~s}^{-1} 300-\mathrm{hPa}$ jet streak extend- ing from the southern Great Lakes to the mid-Atlantic coast and offshore (Fig. 8a). There also is split upper flow, with a subtropical branch of the upper jet extending from northwestern Mexico across the south-central and southeastern United States, and a northern branch jet from south-central Canada, yielding generally confluent flow across the East Coast of the United States. The upper trough is associated with a large negative geopotential height anomaly, with $300-\mathrm{hPa}$ heights 200-m less than the 1979-2001 climatological average over northern New England and southeastern Canada (Fig. 8b). The mid-tropospheric flow also features cyclonic flow across New England with the mean 500$\mathrm{hPa}$ trough axis across New York and Vermont (not shown). The core of strongest 500-hPa winds (35-40 $\mathrm{m} \mathrm{s}^{-1}$ ) was similarly located from southeastern Michigan east-southeastward to off the New Jersey and midAtlantic coast.

Lower-tropospheric cold-air advection is evident in the mean $850-\mathrm{hPa}$ geopotential heights and temperatures just upstream of the study area (Fig. 9a), along with temperatures in the favorable dendrite growth zone. The coldest temperatures $\left(-22^{\circ} \mathrm{C}\right)$ are located south of James Bay. The strongest $850-\mathrm{hPa}$ winds are across western New York into Pennsylvania at 16-18 $\mathrm{m} \mathrm{s}^{-1}$ (32-36 kt; Fig. 9b). Again, northern New York and Vermont are embedded within cyclonic flow. Deep layer cyclonic flow is evident at all tropospheric levels, consistent with the composite environment for 
10m WIND

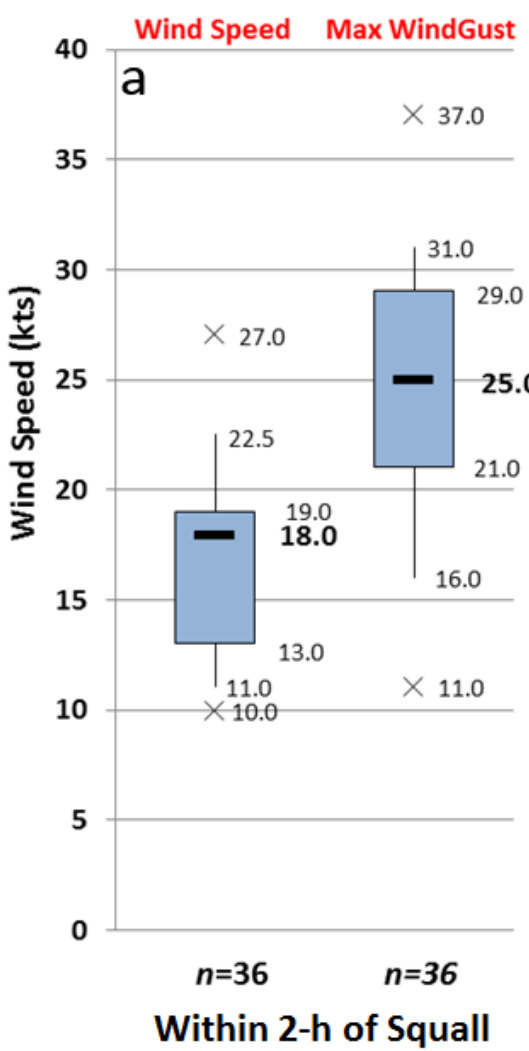

2m TEMPERATURE

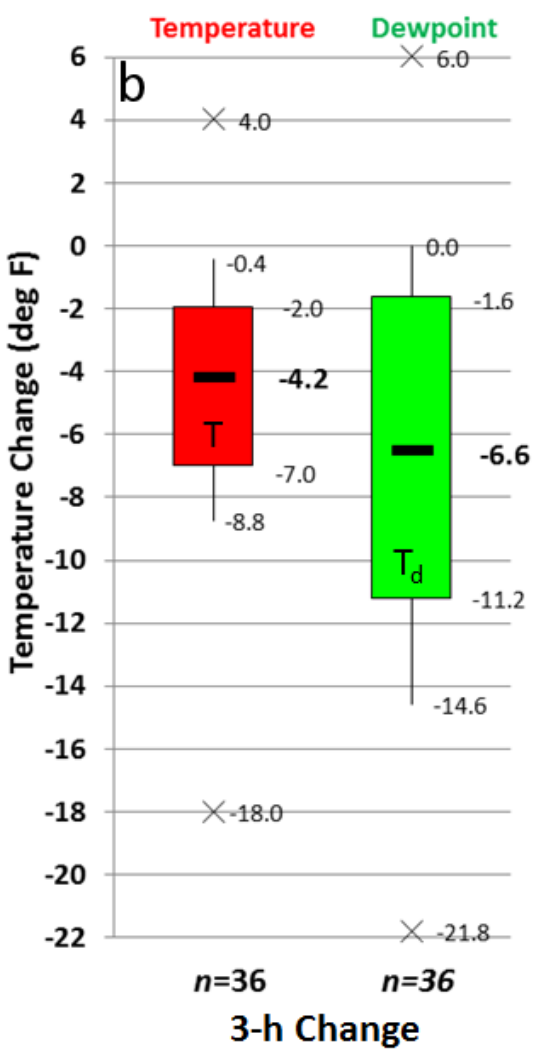

SEA-LEVEL PRESSURE

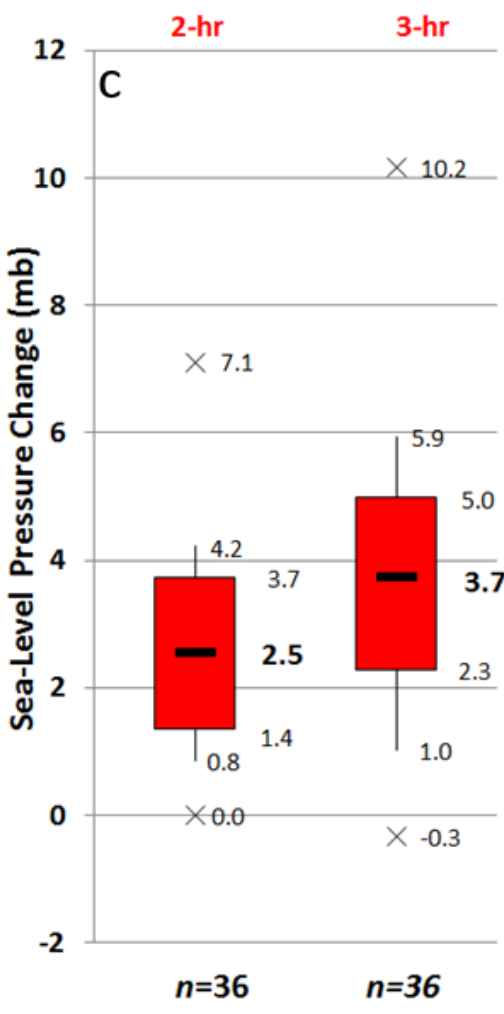

Figure 7. As in Fig 5 except for (a) wind speed and wind gust (kt; multiply by 0.5144 for $\mathrm{m} \mathrm{s}^{-1}$ ) within 2 h of squall occurrence, (b) 3-h temperature and dewpoint change ( ${ }^{\circ} \mathrm{F}$; divide by 1.8 for ${ }^{\circ} \mathrm{C}$ change) following squall occurrence, and (c) sea-level pressure change $(\mathrm{hPa})$ immediately preceding the squall to $2 \mathrm{~h}$ and $3 \mathrm{~h}$ later.
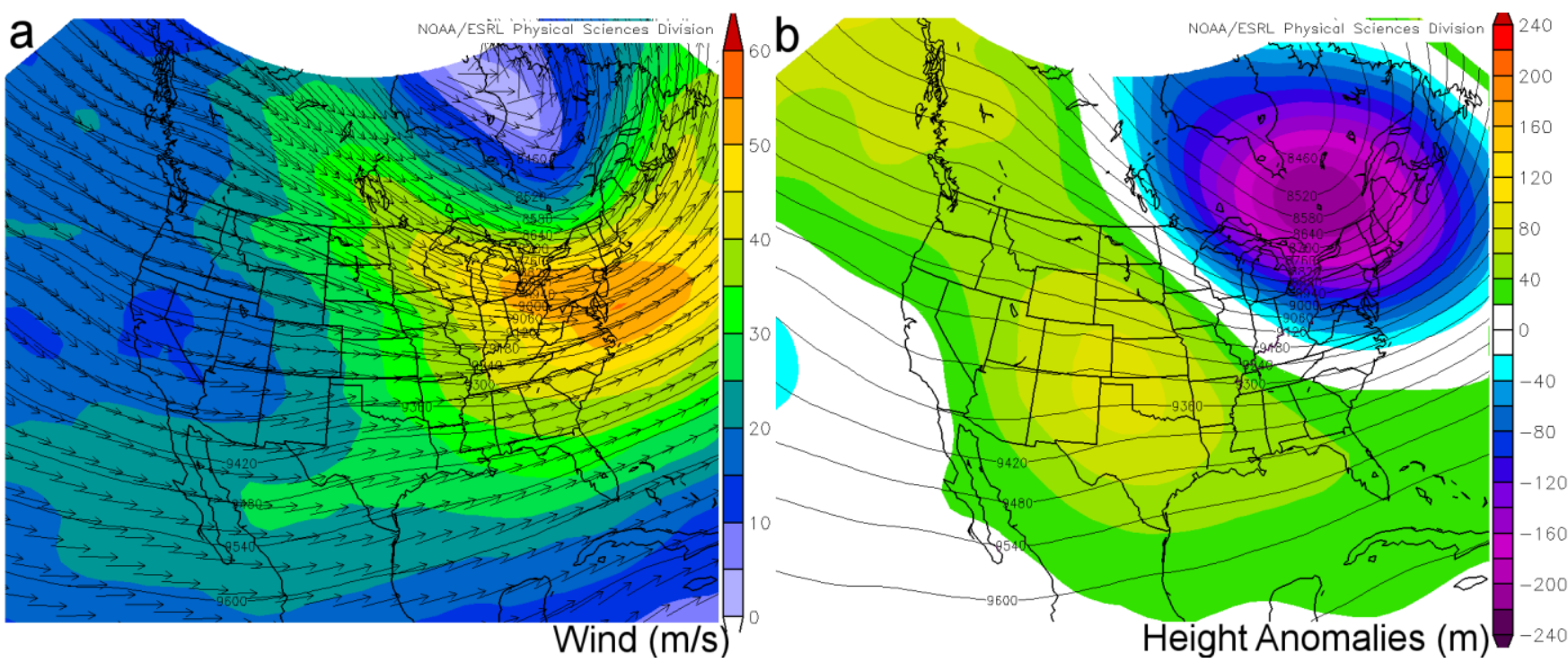

Figure 8. The NARR composite (a) 300-hPa mean geopotential heights (m, solid lines) and winds ( $\mathrm{m} \mathrm{s}^{-1}$, color filled) and (b) 300-hPa mean geopotential heights ( $\mathrm{m}$, solid lines) and 21-day centered height anomalies (color filled) for all 36 snow squall events over the WFO Burlington forecast area. 

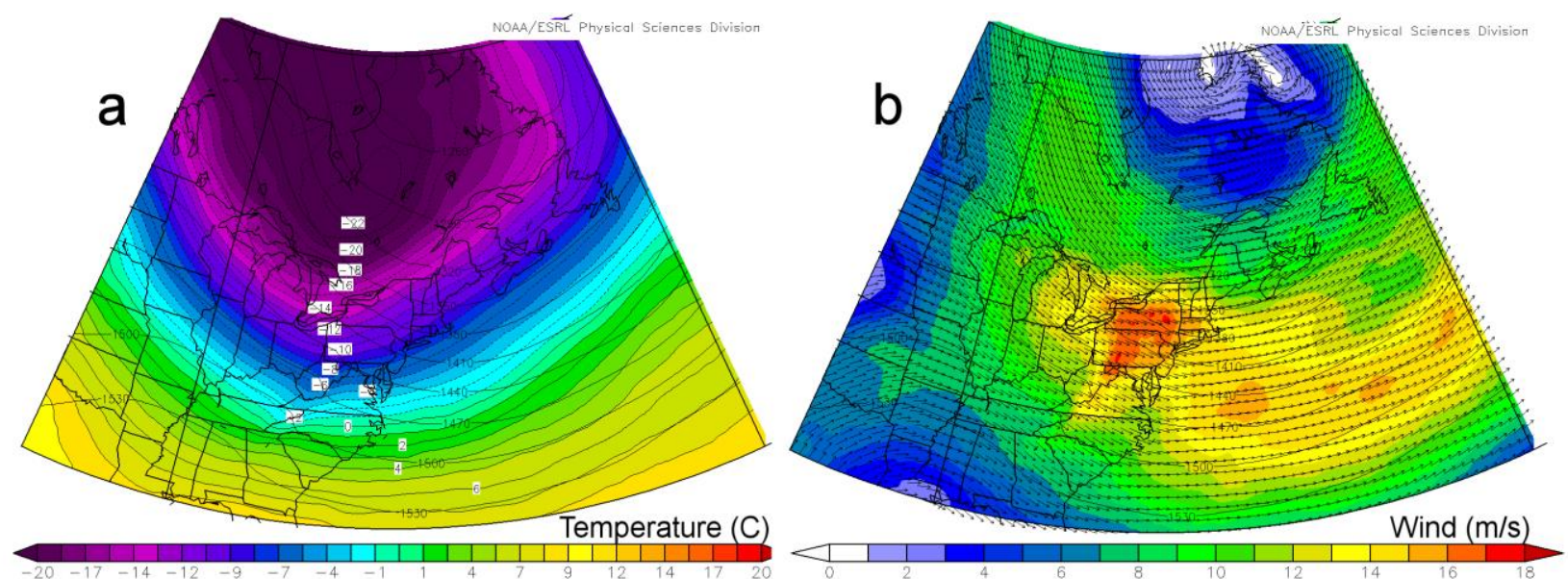

Figure 9. As in Fig. 8 except for (a) composite mean 850-hPa geopotential height (m, solid lines) and temperatures $\left({ }^{\circ} \mathrm{C}\right.$, color filled) and (b) composite mean 850-hPa geopotential height ( $\mathrm{m}$, solid lines) and wind speed ( $\mathrm{m} \mathrm{s}^{-1}$, color filled).

low-dewpoint derechos (Corfidi et al. 2006). At the surface, a cold front is evident in the composite mean with a sea-level pressure trough along the Saint Lawrence River valley. A strong $925-\mathrm{hPa}$ temperature gradient is located just to the north and west across southwestern Quebec and southeastern Ontario (Fig. $10)$.

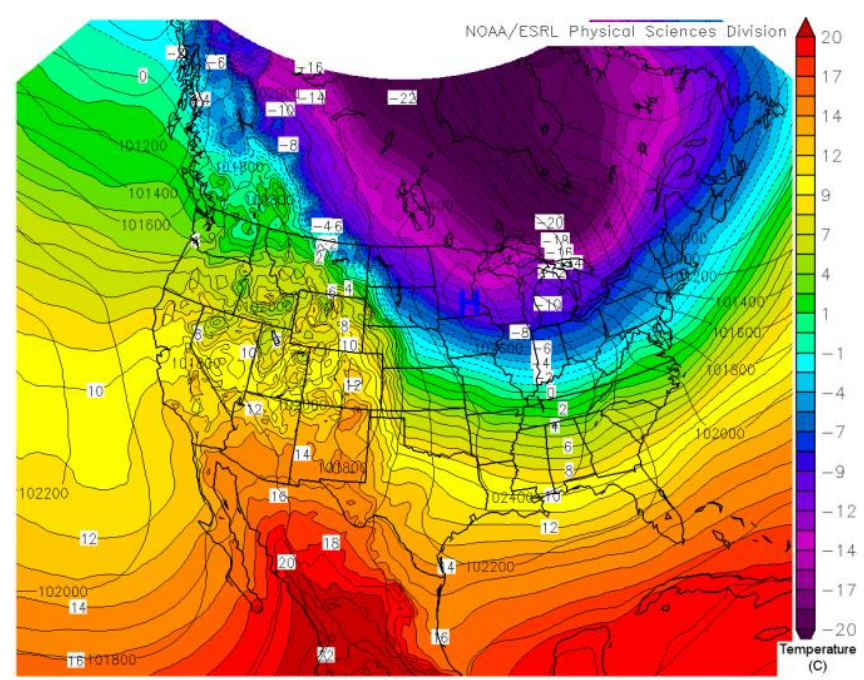

Figure 10. As in Fig. 8, except for composite mean sea-level pressure (hPa, solid lines) and $925-\mathrm{hPa}$ temperatures (color filled, every $1^{\circ} \mathrm{C}$ ).

\section{c. Mesoscale characteristics of snow squalls}

In this subsection, we examine a NAM timeheight cross section for an individual case on 7 December 2008 to show structural characteristics of a snow squall as the system traversed KBTV. The frontal structure is apparent in the strong gradient of equiv- alent potential temperature $\left(\theta_{e}\right)$, especially near and below $1 \mathrm{~km}$ AGL (Fig. 11a). There also is evidence of potential instability (i.e., $\partial \theta_{e} / \partial z<0$ ) indicated by "folding" of the 280-K $\theta_{e}$ surface just in advance of the front. This instability will be realized owing to the upward motion (red solid lines in Fig. 11a) associated with the front.

The intersection of upward motion $\left(-18 \mu \mathrm{b} \mathrm{s}^{-1}\right)$ and saturation in the dendrite growth zone (Fig. 11a) yielded favorable microphysics for heavy snow production (Cobb and Waldstreicher 2005). The highest wind speeds were coincident with the cold frontal passage at 2200 UTC with a maximum of $17.5 \mathrm{~m} \mathrm{~s}^{-1}$ (35 kt) between 0.5 and $1 \mathrm{~km}$ (Fig. 11b). Steep lapse rates -including a MAUL from the surface to $900 \mathrm{hPa}-$ promoted downward momentum transfer and the period of gusty winds at the surface, which gradually lessened in the hours following frontal passage.

Time-height cross sections examined in addition to the 7 December 2008 event (not shown) displayed some similar characteristics: (1) low-level upward motion maximum in the lowest $2 \mathrm{~km}$ AGL along the leading edge of a baroclinic zone, (2) saturation in the lowest $2-3 \mathrm{~km}$ AGL coincident with potential instability, and (3) relatively strong low-level horizontal wind speeds, with a maximum just to the cold side of the surface front. This is consistent with the strong linear ascent found in severe wind-producing MCSs associated with low moisture and instability values (Corfidi et al. 2006). As such, it is useful for forecast purposes to view snow squalls as a cold-season type of MCS. Given smaller instability values and lesser precipitation loading and evaporative cooling effects, it seems 


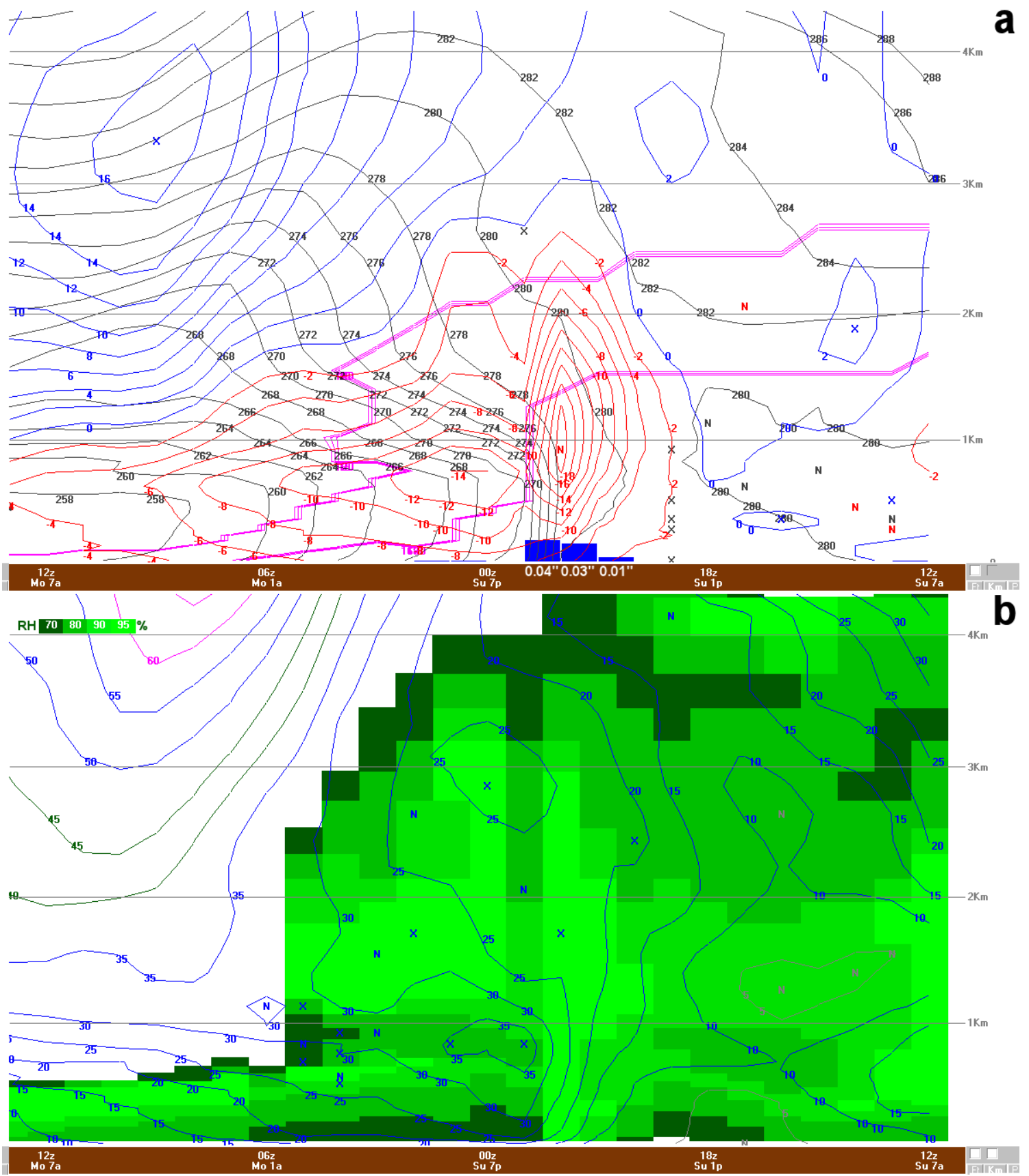

Figure 11. Time-height cross sections of the NAM run at 1200 UTC 7 December 2008 at Burlington, VT (KBTV), as viewed in BUFKIT. Panel (a) shows contours of $\theta_{e}$ (black solid lines, every $2^{\circ} \mathrm{K}$ ), upward (red solid) and downward (blue solid) motion $\left(\mu \mathrm{b} \mathrm{s}^{-1}\right.$ ), and the band of favorable dendrite snow growth (within the purple lines) where the air temperature was between $-12^{\circ} \mathrm{C}$ and $-18^{\circ} \mathrm{C}$ and saturated with respect to ice. The hourly quantitative precipitation forecast from the NAM is shown as annotated blue bars (in; multiply by 2.54 for $\mathrm{cm}$ ). Panel (b) shows the relative humidity (shaded green for $\geq 70 \%$ ) and isotachs (solid lines, kt; multiply by 0.5144 for $\mathrm{m} \mathrm{s}^{-1}$ ).

likely that the linear organization of convective precipitation and winds are reliant on upscale (i.e., frontogenetic and synoptic-scale) forcing to bring about the squall and forward propagation, rather than through cold pool dynamics induced by the convection itself.

\section{d. Thermodynamic and wind environment}

Snow squall characteristics evident in the archived NAM time-height cross sections focused further examination on the low-level wind, moisture, and instability environment for the sample of 36 snow squall events 
over Vermont and northern New York using NARR data analyzed via GEMPAK. Summarized below are results for some of the key environmental parameters for the snow squall events and the 1201 time steps available from the 2005-06 control dataset.

The $0-2-\mathrm{km}$ AGL mean wind speed had a median value of $11.6 \mathrm{~m} \mathrm{~s}^{-1}$ (22.5 kt) for the 36 snow squall events, with an interquartile range of $9-13.1 \mathrm{~m} \mathrm{~s}^{-1}$ (17.5-25.5 kt) (Fig. 12a). The control sample generally had lower wind speeds [median of $8.4 \mathrm{~m} \mathrm{~s}^{-1}(16.3 \mathrm{kt})$ ], though there is considerable overlap between the two samples. The low-level relative humidity (RH) also showed overlap between the two datasets, but with the snow squall events slightly more moist and covering a smaller interquartile range (Fig. 12b).

Larger differences were found in the instability measures. Whereas a typical winter day has no surface-based CAPE, the snow squall database had a median value of $36 \mathrm{~J} \mathrm{~kg}^{-1}$, which is above the 90th percentile of the control database (Fig. 12c). Similarly, the 0-2-km AGL $\theta_{e}$ difference displayed large positive values for the control database (interquartile range of $4.5-15.5^{\circ} \mathrm{C}$ ), but had values clustered near zero for the snow squall cases (median of $-1.0^{\circ} \mathrm{C}$ ) owing to the presence of neutral stability or potential instability for the majority of events (Fig. 12d). The moistureinstability parameter space revealed clustering of the snow squall cases toward unstable, high moisture environments relative to the control sample (Fig. 13). The clustering of data in the scatterplot highlights the potential forecast value that can be extracted from the low-level moisture and instability fields.

\section{Forecasting snow squalls and the snow squall pa- rameter}

An ingredients-based approach to forecasting snow squalls would necessarily include the traditional triad of ingredients for moist convection (moisture, instability, and a source of lift; Doswell 1987)—plus others including sufficient low-level wind magnitude and a vertical temperature profile supporting snow. Visualization of these ingredients might include a 4panel display including sea-level pressure, $0-2-\mathrm{km}$ $\mathrm{RH}$, surface-based CAPE or 0-2-km $\theta_{e}$ difference, and some measure of the low-level mean wind speed (lowest 0-2 km for consistency). An AGL perspective is important; parameters based on pressure-levels can be compromised near the ground owing to surface elevation differences. One could use mass convergence to infer the presence of upward motion through mass continuity, but in the complex terrain of northern New York and Vermont, mobile areas of low-level convergence were difficult to identify within a quasisteady field of convergence associated with upslope and downslope signatures induced by flow over the orography. Because squalls are surface-based features typically near fronts, an alternative is to plot 2-h or 3-h isallobars, where the leading edge of the strongest isallobaric rise gradient is generally along the axis of strongest low-level convergence ${ }^{1}$. Since station pressure measurements are reduced to sea-level, this effectively eliminates the terrain-related influences and allows the forecaster to visualize areas of convergence stemming from the isallobaric wind and associated transient pressure couplets. Inclusion of low-level isotherms or $\theta_{e}$ lines also is useful, consistent with the baroclinic zones observed in the snow squall synoptic climatology and time-height cross sections. Low-level frontogenetic forcing can be examined to assess upward motion with the associated thermally direct circulation. Four-panel visualization examples are shown in section 5 .

For a quick diagnosis, some forecasters use a single composite parameter to highlight the favored areas for a particular atmospheric phenomenon. Examples of such parameters include the significant tornado parameter and supercell composite parameter (Thompson et al. 2003, 2004), available from the Storm Prediction Center (www.spc.noaa.gov/exper/mesoanalysis/). Doswell and Schultz (2006) point out potential limitations associated with such approaches, and these types of composite parameters do not have physical meaning. However, when properly validated they can be shown to have diagnostic utility, especially for situational awareness purposes under ever-present operational time pressures. Since situational awareness is particularly problematic for these low quantitative precipitation forecast snow squall events, it is advantageous to have a graphical way to highlight favored areas for snow squalls. With the forecaster's attention focused on a potential snow squall, a more thorough diagnosis then can take place, which can be based in an ingredients-based approach.

Our approach to a composite snow squall parameter highlights where it is moist, unstable, windy, and

\footnotetext{
1 The geostrophic wind is non-convergent on an $f$ plane. The ageostrophic wind can be broken into the isallobaric and inertial-advective components, with the isallobaric wind typically larger near the surface.
} 

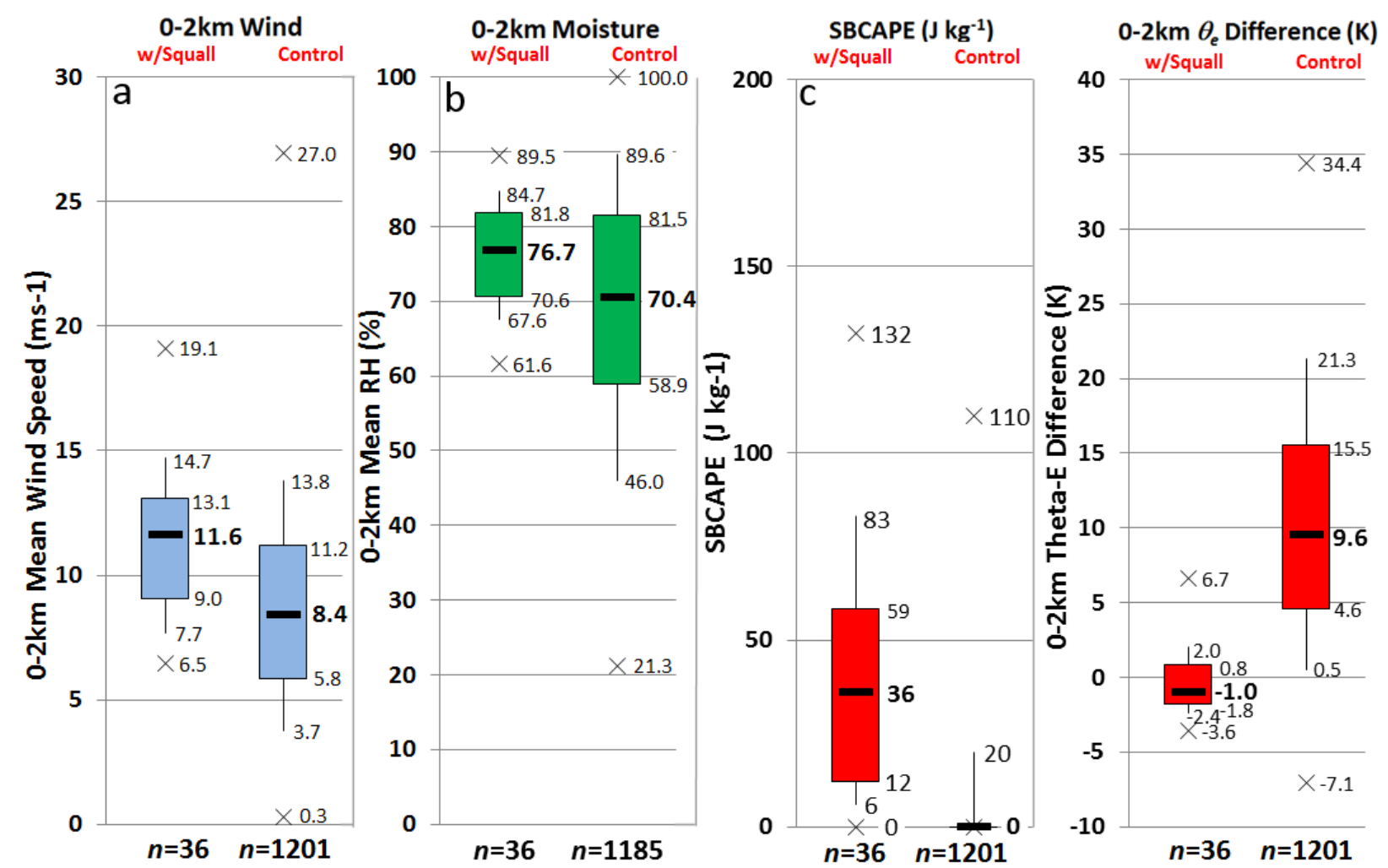

Figure 12. As in Fig. 5, except for the NARR data closest in time to snow squall occurrence interpolated to the METAR station affected by the snow squall (denoted by "w/Squall"). The "Control" includes all available time steps from 1 November 2005 through 31 March 2006. Shown are (a) the 0-2-km AGL mean wind speed ( $\mathrm{m} \mathrm{s}^{-1}$ ), (b) the 0-2-km AGL mean RH (\%), (c) surface-based CAPE $\left(\mathrm{J} \mathrm{kg}^{-1}\right)$, and (d) 0-2-km AGL $\theta_{e}$ difference (K). There were 16 unavailable RH grids from the NARR, resulting in a smaller sample for that variable.

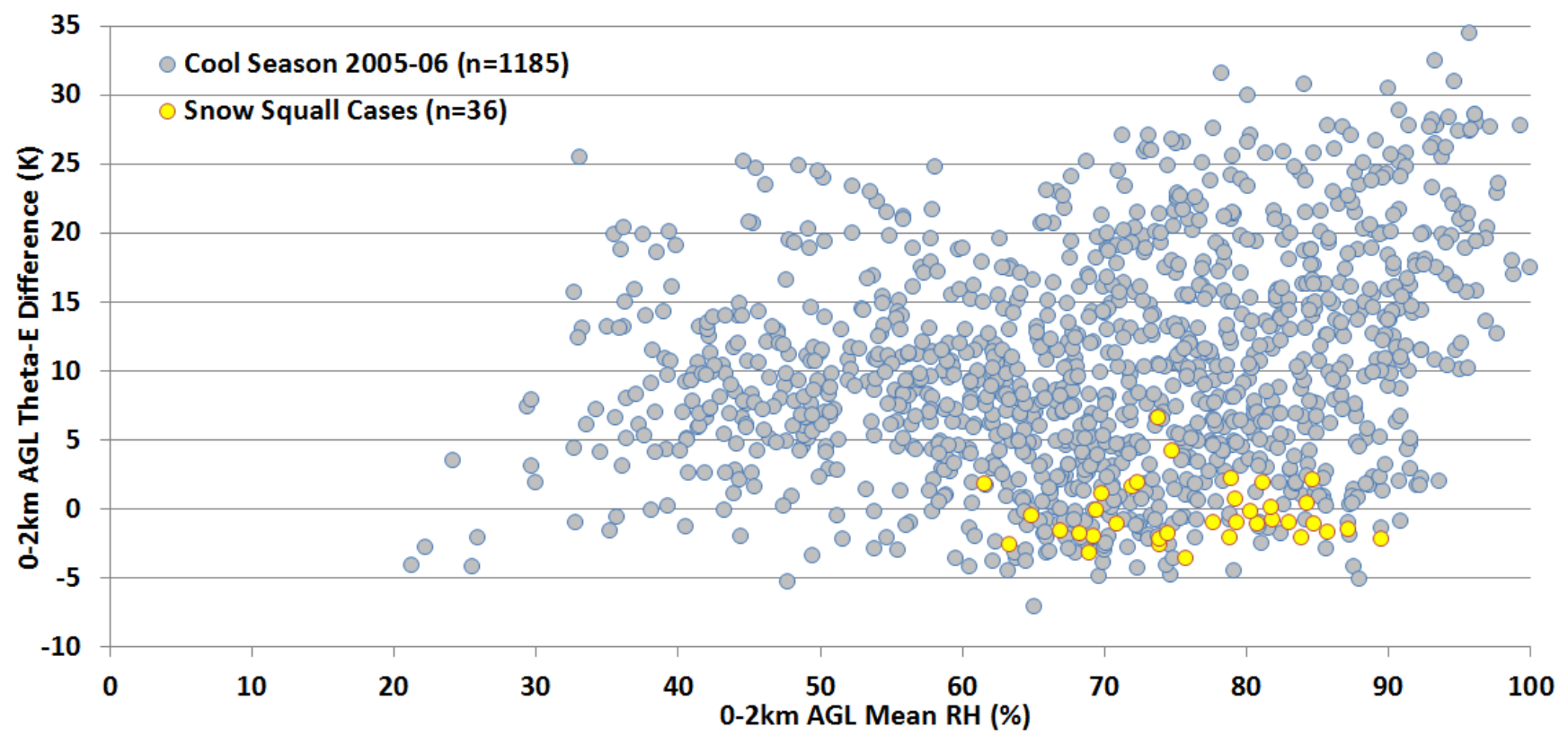

Figure 13. Scatterplot of the 0-2-km AGL $\theta_{e}$ difference (K) versus 0-2-km AGL mean RH (\%) for the 36 snow squall events (yellow dots) and the 2005-06 control dataset (gray dots). 
cold enough for snow, based on the NARR results. Accordingly, the SNSQ was setup as follows:

$$
\begin{aligned}
S N S Q= & \left(\frac{\overline{R H}_{s f c-2 k m}-60 \%}{15 \%}\right) * \\
& \left(\frac{4 K-\left(\left.\theta_{e}\right|_{2 k m}-\left.\theta_{e}\right|_{s f c}\right)}{4 K}\right) *\left(\frac{\|\vec{V}\|_{s f c-2 k m}}{9 m s^{-1}}\right)
\end{aligned}
$$

where $\overline{R H}_{s f c-2 k m}$ is the mean RH in the surface (i.e., $2 \mathrm{~m})$ to $2-\mathrm{km}$ AGL layer, $\left.\theta_{e}\right|_{2 k m}-\left.\theta_{e}\right|_{s f c}$ is the vertical equivalent potential temperature difference between the surface and $2 \mathrm{~km} \mathrm{AGL}$, and $\|\overrightarrow{\vec{V}}\|_{s f c-2 \mathrm{~km}}$ is the mean wind speed in the surface to 2-km AGL layer. Each of the factors in (1) was calibrated using the snow squall dataset distribution (Fig. 12) using a value between the 25th and 50th percentile to achieve a value of 1.0 for a favorable condition of that variable. Values $>1.0$ for each factor contribute to a larger SNSQ, which generally means a more favorable environment for snow squalls. As also can be seen in Eq. (1), the SNSQ approaches zero as any one factor approaches zero; this is preferable as each factor is considered necessary for the occurrence of snow squalls. If either or both of the first two factors become negative, the equation also is set to zero (to avoid having a positive result if both the $\mathrm{RH}$ and instability factors contribute negative values). Since lapse rates tend to be steep in association with snow squalls, a test of the boundary layer temperature is generally sufficient to exclude environments that are too warm for snow (near-surface melting is the only issue). A wet-bulb threshold of $1^{\circ} \mathrm{C}$ is set at $2 \mathrm{~m}$, with the SNSQ "zeroed out" in areas where the surface wetbulb temperature exceeds this value. The factor which includes the surface-2-km AGL wind speed helps to eliminate near-zero wind environments not prone to snow squall development. Lift is assessed independently; because the convection is surface-based and strongly forced, the presence of surface isallobaric couplets and low-level frontogenesis generally is helpful for finding areas of linear ascent (often coincident with cold or arctic frontal boundaries).

From NARR data ${ }^{2}$, the SNSQ was calculated for all 36 cases in our dataset, yielding a median value of 1.0. The 2005-06 control dataset had a median value of zero (Fig. 14), indicating good separation between a

2 For similar environments, SNSQ values generally are greater when higher spatial and/or temporal resolution data are used as input, owing to better resolution of convective-scale processes. winter day without snow squall activity and the value associated with the nearest NARR time step to snow squall occurrence. The time series analysis (Fig. 15) of the SNSQ also shows the relatively infrequent occurrence of positive SNSQ values, subjectively indicating a good signal-to-noise ratio. Finally, the probability of detection (POD) for all 36 cases and the false alarm ratio (FAR) based on the 2005-06 control was calculated-assuming a snow squall "yes" forecast at a particular threshold of the SNSQ (Fig. 16). As expected, nearly all events are captured at a value of 0.1 , but the POD drops off as some events are "missed" as a progressively higher threshold is used. Likewise, the FAR is $0.4-0.5$ at values of SNSQ $<1.0$. However, if a lower threshold of visibility is applied $[4.8 \mathrm{~km} \mathrm{(3 \textrm {mi } )}$ instead of $0.8 \mathrm{~km}(0.5 \mathrm{mi})]$, the FAR is considerably lower (0.1-0.25), suggesting that many of the false alarms are "near misses," having convective snow

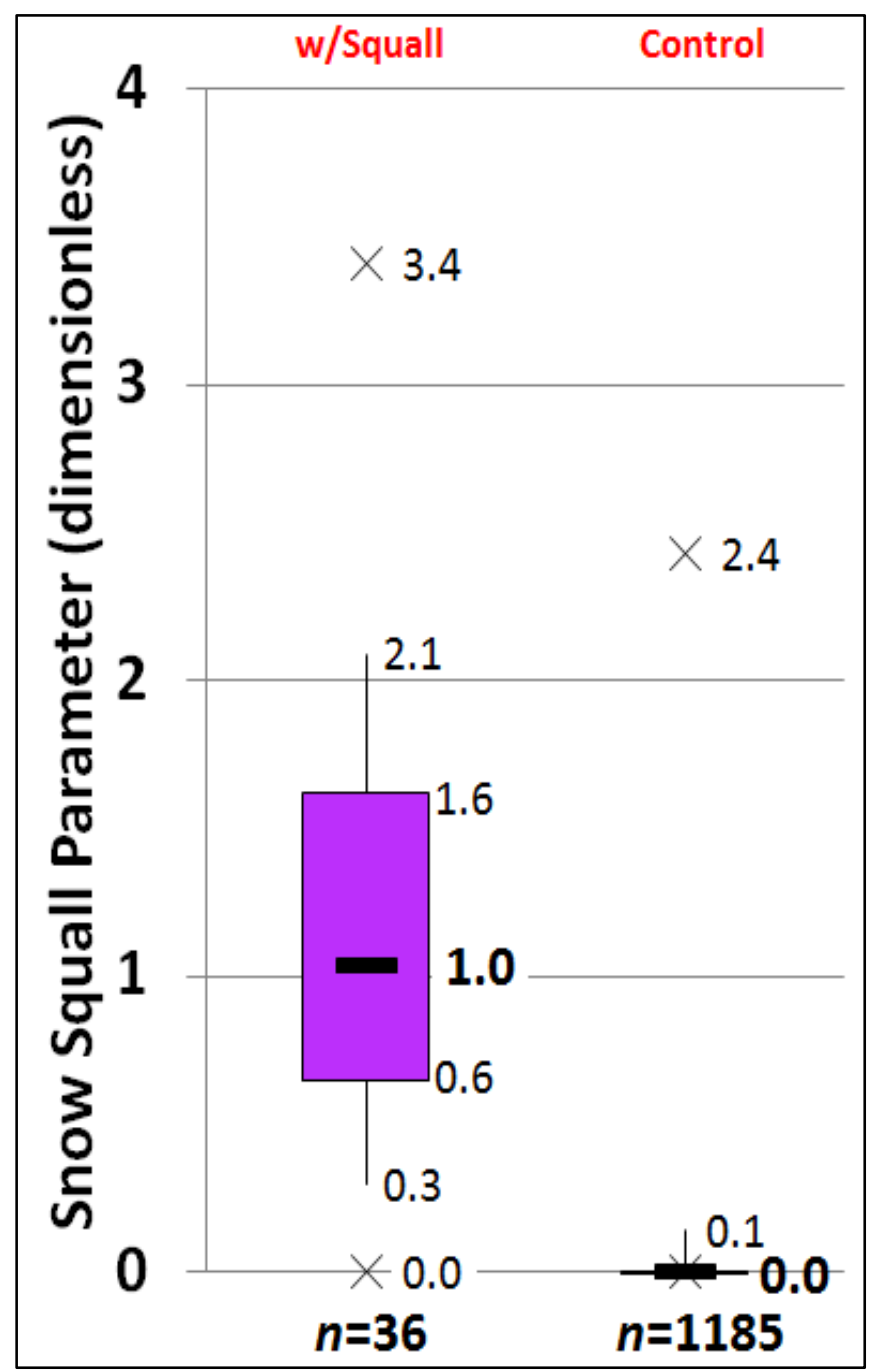

Figure 14. As in Fig. 12 except for the SNSQ (non-dimensional). 


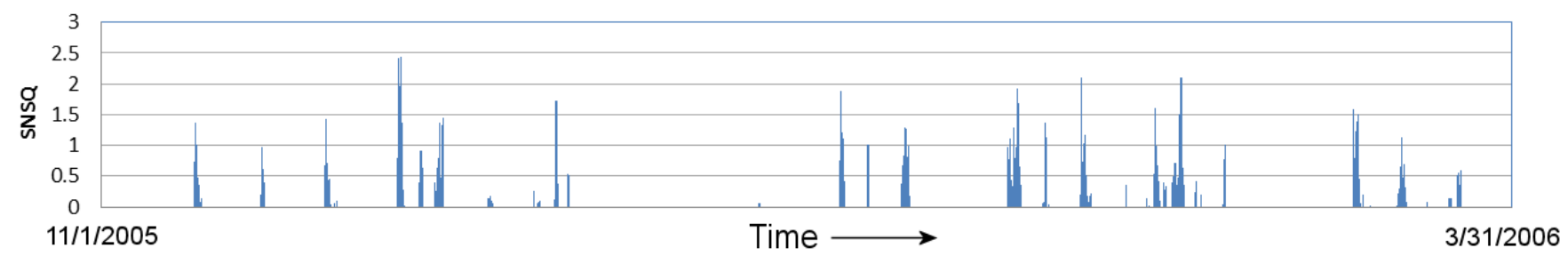

Figure 15. Time series of 3-h NARR data interpolated at Burlington, VT, showing value of the SNSQ (non-dimensional) from 1 November 2005 through 31 March 2006.

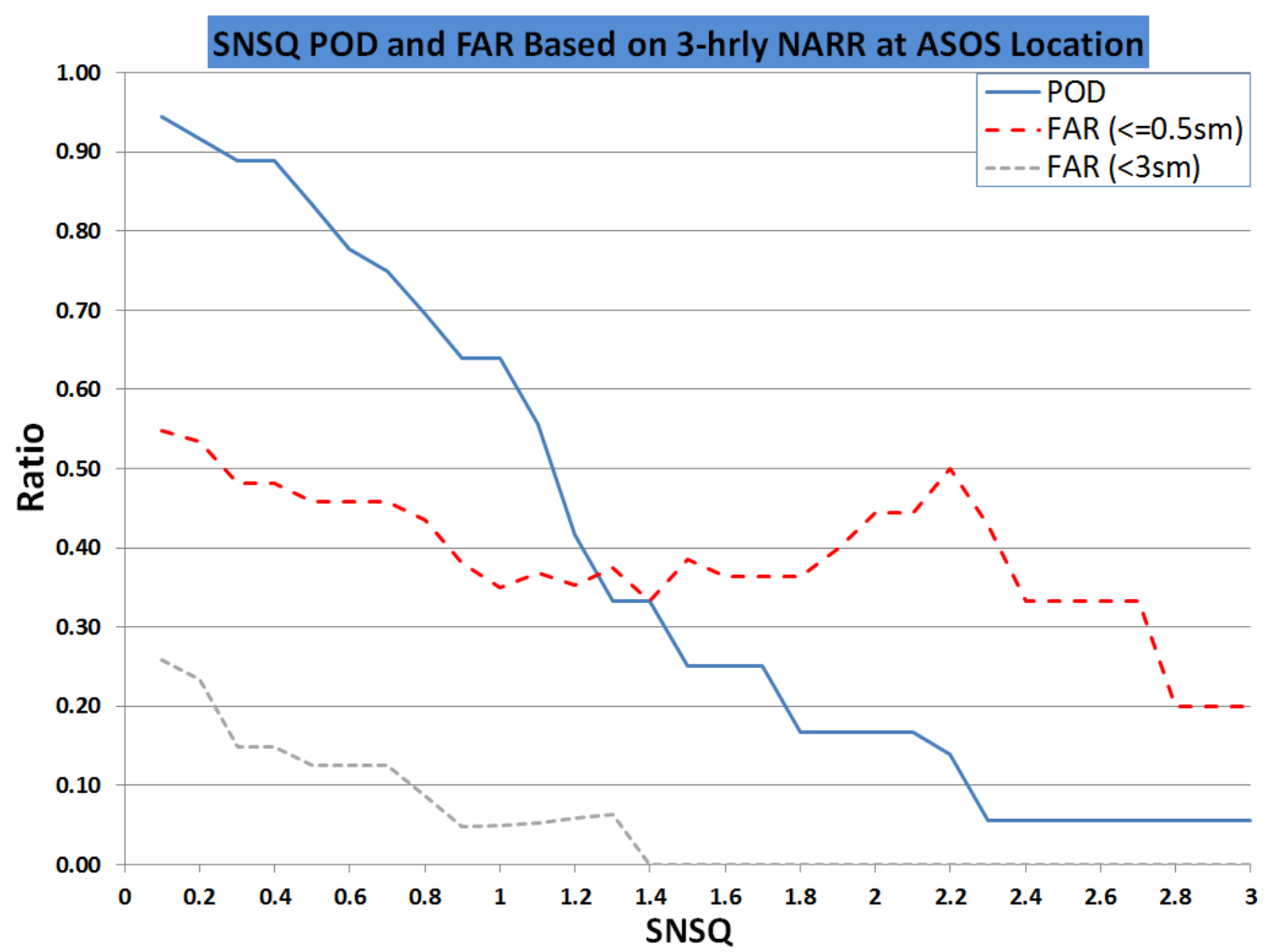

Figure 16. Plot of probability of detection (POD, solid blue line) and false alarm ratio (FAR, dashed red line) for snow squall forecasts at a visibility threshold of $\leq 0.8 \mathrm{~km}(0.5 \mathrm{mi})$. The FAR at a visibility threshold corresponding to an IFR condition $[<4.8 \mathrm{~km}(3 \mathrm{mi})]$ also is shown (dashed gray line). The POD is derived from the 36 snow squall case dataset. The FAR is based on the 2005-06 control dataset.

showers that are just above the $0.8-\mathrm{km}(0.5 \mathrm{mi})$ visibility threshold. Regardless, high FARs are a general problem with these types of multivariable parameters and have been observed in other applications using a similar approach (Thompson 2003, 2004). The above results suggest that the SNSQ is a reasonable diagnostic for assessing favorable snow squall environments. Our recommendation is to use the SNSQ as a first step prior to an in-depth assessment of the thermodynamic, kinematic, and dynamic forcing regime in question for forecast refinement.

\section{Snow squall case studies}

a. 17 January 2013: Southeastern Canada into northern New England

Snow squalls on 17 January 2013 are used to demonstrate the predictive efficacy of the SNSQ and 4panel layouts in identifying snow squall environments using NARR data. An arctic frontal boundary swept across a large portion of Ontario and Quebec on the evening of the 16th (Fig. 17) and into northern New England during the early to mid-morning hours on the 17th. Surface observations indicated that the arctic 

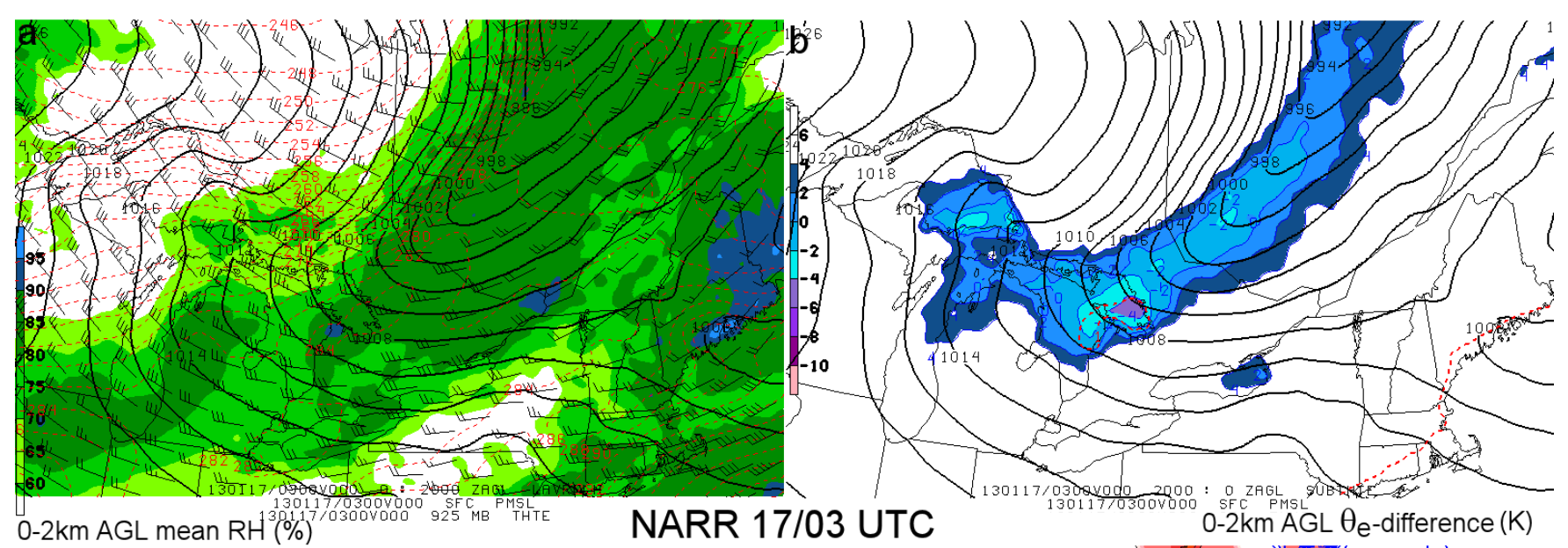

NARR 17/03 UTC
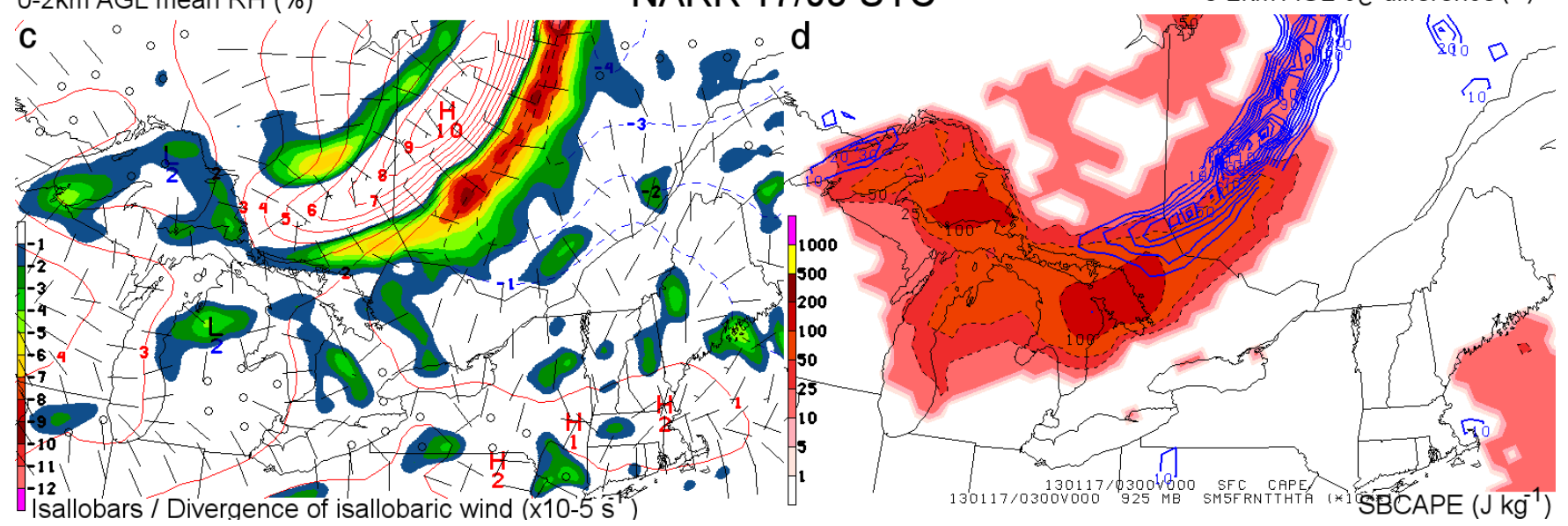

Figure 17. NARR depiction at 0300 UTC 17 January 2013 of (a) mean 0-2-km AGL RH (color filled, \%) with sea-level pressure (black lines, every $2 \mathrm{hPa}$ ), mean $0-2-\mathrm{km}$ wind (full barb $=5 \mathrm{~m} \mathrm{~s}^{-1}$ ), and 925-hPa $\theta_{e}$ (red dashed lines, every $2^{\circ} \mathrm{K}$ ); (b) $0-2-\mathrm{km} \mathrm{AGL} \theta_{e}$ difference, sea-level pressure (black lines, every $2 \mathrm{hPa}$ ), and the $1^{\circ} \mathrm{C}$ wet-bulb isotherm at $2 \mathrm{~m}$ AGL (red dashed line); (c) 3-h sea-level isallobars (every $1 \mathrm{hPa}$ ) with isallobaric wind (full barb $=5 \mathrm{~m} \mathrm{~s}^{-1}$ ), and divergence of the isallobaric wind (convergent areas shaded, $10^{-5} \mathrm{~s}^{-1}$ ); and $(\mathrm{d}$ ) surface-based CAPE $\left(\mathrm{J} \mathrm{kg}^{-1}\right)$ and $925-\mathrm{hPa}$ Petterssen frontogenesis [blue lines, positive values every $10 \mathrm{~K}(100 \mathrm{~km})^{-1}(3 \mathrm{~h})^{-1}$ ].

front was producing snow squalls as it progressed across eastern Ontario and Quebec (Table 3); visibilities as low as $0.2 \mathrm{~km}(0.13 \mathrm{mi})$ in heavy snow with rapidly falling surface temperatures (from $-4^{\circ} \mathrm{C}$ to $-14^{\circ} \mathrm{C}$ in $20 \mathrm{~min}$ at Mattagami Airport) were observed. The arctic front gradually weakened as it crossed the international border, but still produced visibilities as low as $0.4 \mathrm{~km}(0.25) \mathrm{mi}$ at Saranac Lake, New York, and resulted in snow-covered road conditions during the morning commute.

The low-level thermodynamic and moisture conditions that led to snow squall development based on the NARR depiction are shown in Fig. 17. Steep low-level lapse rates-inferred by a negative vertical $\theta_{e}$ difference in the 0-2-km AGL layer (Fig. 17b) - combined with saturated conditions in that layer (Fig. 17a), resulted in surface-based CAPE values of up to $100 \mathrm{~J}$ $\mathrm{kg}^{-1}$ (Fig. 17d). Strong isallobaric wind convergence (shaded in Fig. 17c) suggested linear forcing for ascent along the arctic front at 0300 UTC 17 January, which is associated with low-level frontogenetic forcing (Fig. $17 \mathrm{~d})$. The combination of the $0-2-\mathrm{km}$ AGL $\theta_{e}$ difference and saturated $0-2-\mathrm{km}$ RH contributed to SNSQ values between 2 and 5 (Fig. 18a). Canadian composite reflectivity (Fig. 18d) shows the linear organization of the snow squalls collocated with positive values of the SNSQ and strongest isallobaric gradient. Associated ascent can be inferred from the convergence of the isallobaric wind along the baroclinic zone (Fig. 17c). Figures $18 \mathrm{~b}$ and $18 \mathrm{c}$ show decreasing SNSQ values with the weakening frontal boundary in northern New York and Vermont, with a decrease in low-level isallobaric wind convergence (not shown). Composite reflectivity indicated that the convection became less organized through 1500 UTC as low-level frontal ascent weakened across northern New York and Vermont (not shown). However, the stronger isallobaric convergence and higher values of the SNSQ depicted 
Table 3. Listing of Canadian METAR reports associated with the snow squall on 16-17 January 2013.

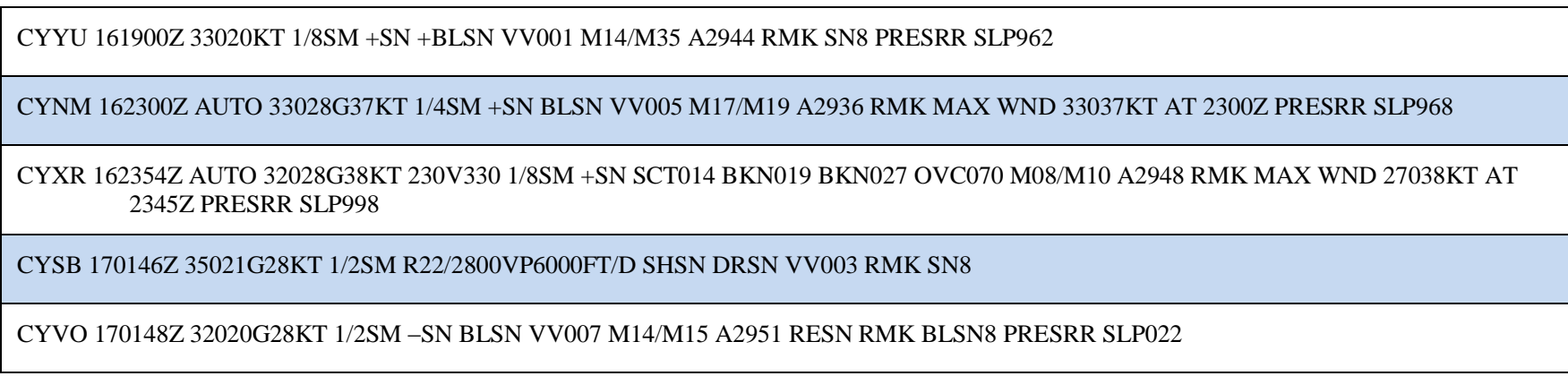

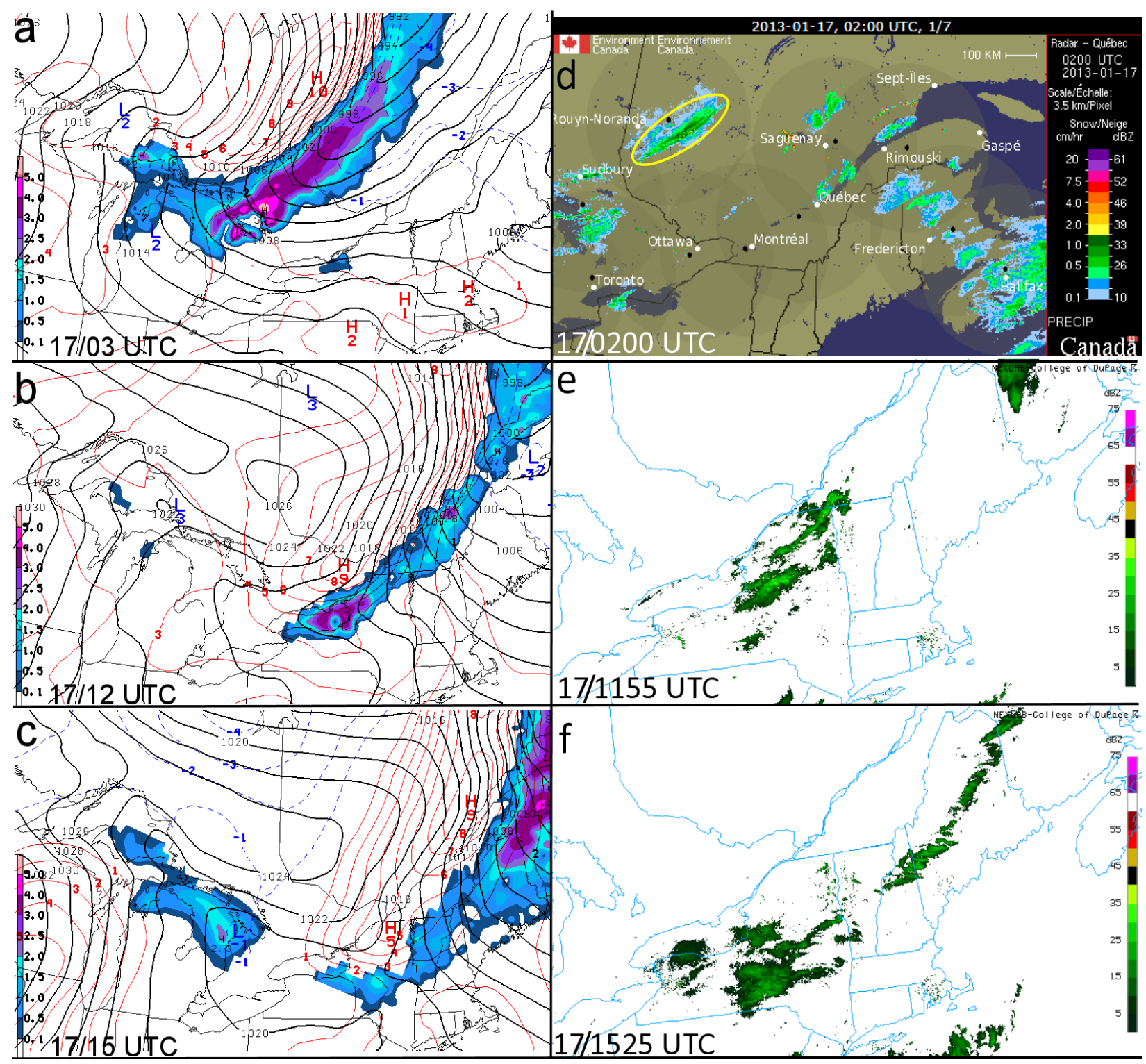

Figure 18. The NARR depiction of the SNSQ (color filled, non-dimensional) plotted with sea-level pressure (black lines, every 2 $\mathrm{hPa}$ ) and 3-h isallobars (every $1 \mathrm{hPa}$; red solid lines indicate rises and blue dashed lines indicate falls) for 17 January 2013 at (a) 0300 UTC, (b) 1200 UTC, and (c) 1500 UTC. In (d) the Canadian mosaic composite reflectivity (dBZ) at 0200 UTC 17 January 2013 shows a line of snow squall activity southeast of Landrienne, Quebec (denoted by yellow ellipse). The WSR-88D mosaic composite reflectivity over the northeastern United States on 17 January 2013 is given in (e) 1155 UTC and (f) 1525 UTC. 
over northern Maine at 1500 UTC (Fig. 18c) were associated with heavy snow at Caribou, Maine, beginning at 1505 UTC.

\section{b. 11 February 2003: Midwestern snow squall}

The 11-12 February 2003 "snow derecho" case was chosen to demonstrate applicability of the SNSQ to an area outside the study domain (Midwest and Great Lakes). The 11-12 February 2003 snow squall event resembled a cool-season derecho (Burke and Schultz 2004; Corfidi et al. 2006) and produced a combination of severe wind gusts [(i.e., $\geq 25.7 \mathrm{~m} \mathrm{~s}^{-1}$ (50 kt)], cloud-to-ground lightning, and up to $7.6 \mathrm{~cm}$ (3 in) of snow within one hour across an area from the Dakotas to New York over a period of $21 \mathrm{~h}$ (Fig. 19). A detailed analysis of the event can be found in Pettegrew et al. (2009).

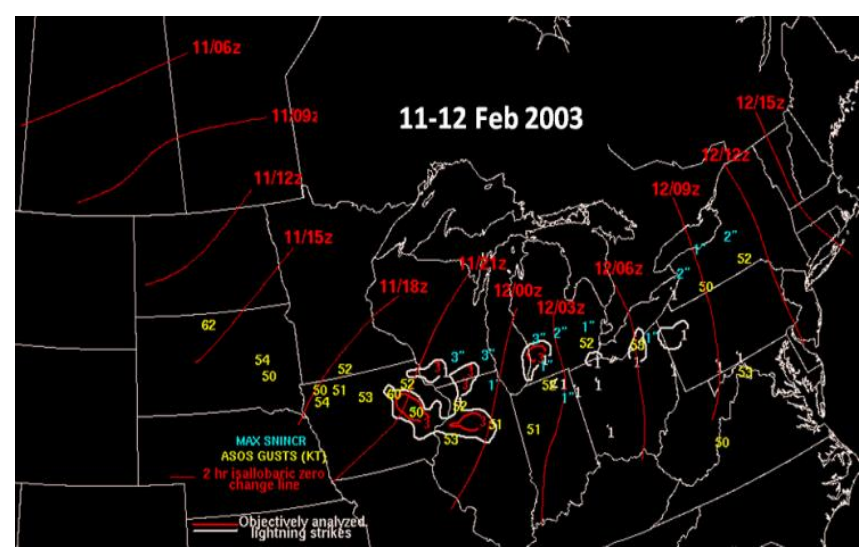

Figure 19. Isochrones (red lines) showing approximate position of a squall line during the period 0600 UTC 11 February 2003-1500 UTC 12 February 2003. Yellow values show peak wind gusts as recorded by ASOS stations (kt; multiply by 0.5144 for $\mathrm{m} \mathrm{s}^{-1}$ ). Cyan values correspond to maximum hourly snowfall amounts associated with snow squall passage at ASOS stations. Cloud-to-ground lightning data based on the National Lightning Detection Network (Orville 2008) are objectively analyzed on $40 \mathrm{~km} \times 40 \mathrm{~km}$ grid at thresholds of one and three strikes for the period 2000 UTC 11 February 2003-1200 UTC 12 February 2003.

Using the NARR, the SNSQ combined with sealevel pressure and surface isallobars (Figs. 20a-c) effectively highlights the most significant area of snow squall activity apparent in mosaic composite reflectivity at 2100 UTC 11 February, 0000 UTC 12 February, and 0300 UTC 12 February (Figs. 20d-f). The greatest SNSQ values are just upstream of the most intense activity in the radar comparisons, likely owing - in this case - to the very strong 0-2-km AGL wind speeds that are upstream of the greatest instability and moisture. This is where the leading edge of the favorable SNSQ values and the leading edge of the strongest isallobaric gradient can be useful for inferring the onset of heavy snow and squall conditions (Fig. 21c). There are other areas with nonzero values of the SNSQ, which corresponded to convective snow shower activity across the northern Great Lakes (lakeeffect snow) and the central Appalachians. The linearly organized frontal snow squalls occurred with the favorable low-level moisture, instability, and wind regime encapsulated by the SNSQ, in combination with the frontogenetic forcing (convergence and lowlevel ascent) where the isallobaric gradient was strongest.

\section{c. 2 January 2012: Upper Ohio Valley and western Pennsylvania}

A snow squall and flash-freeze event affected portions of the Ohio Valley, the eastern Great Lakes, and northern New England on 2 January 2012. Four fatalities and dozens of injuries were reported, along with interstate highway closures across several states. The most severe impacts were (1) a 41-vehicle pileup on I-75 in northern Kentucky, (2) 30+ accidents on I70 near Saint Clairsville, Ohio, (3) a 30-vehicle pileup on I-77 near Beckley, West Virginia, (4) several multivehicle pileups in Indianapolis, Indiana, (5) a 30vehicle pileup in Jefferson County, Pennsylvania, and (6) a morning pileup on Lake Shore Drive in Chicago, Illinois. The evolution of this case is compelling to examine in terms of convective mode and observed road surface conditions.

Partial melting and refreezing of falling snow on untreated highways led to extensive road icing in this case. The snow squalls followed multiple days with above-freezing minimum temperatures and widespread soaking rains from the Ohio Valley to western New England on 28 December 2011 - and additional rain on 1 January 2012. Runoff from rainfall possibly reduced or eliminated all prior road treatments. Lowlevel cold-air advection early on 2 January 2012 allowed surface temperatures to fall below $0^{\circ} \mathrm{C}$ from west to east.

Snow squalls developed during the morning and afternoon of 2 January 2012. At 1800 UTC, positive values of the SNSQ covered a rather broad area from the central Great Lakes east and southeast across New York and northern New England, as well as portions of the upper Ohio Valley (Fig. 22a). The SNSQ favorably encompassed the widely scattered snow showers evident on mosaic composite reflectivity at 

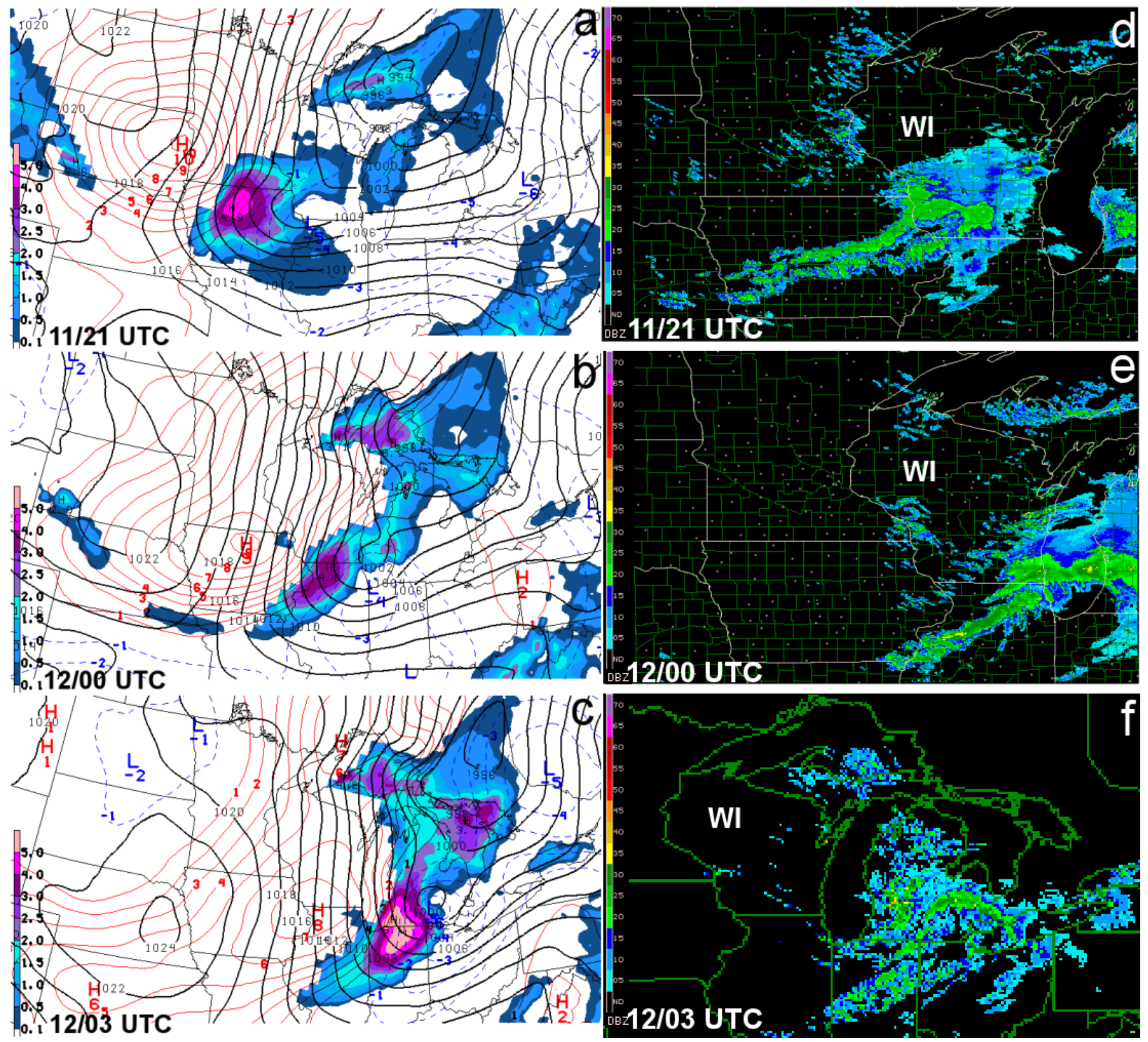

Figure 20. The NARR depiction for the SNSQ (color filled, non-dimensional) plotted with sea-level pressure (black lines, every $2 \mathrm{hPa}$ ) and 3-h isallobars (every $1 \mathrm{hPa}$; red solid lines indicate rises and blue dashed lines indicate falls) at (a) 2100 UTC 11 February 2003, (b) 0000 UTC 12 February 2003, and (c) 0300 UTC 12 February 2003. The mosaic composite reflectivity (dBZ) is given at (d) 2100 UTC 11 February 2003, (e) 0000 UTC 12 February 2003, and (f) 0300 UTC 12 February 2003.

1755 UTC (Fig. 22b). Unlike the frontally forced snow squall cases, the absence of linear forcing in this case resulted in cellular convective activity within a broad region of surface-based CAPE of $50-100 \mathrm{~J} \mathrm{~kg}^{-1}$ and 0 2-km mean $\mathrm{RH} \geq 60 \%$ (Fig. 23). This further suggests that the strong convergence of the isallobaric wind is an indicator of linear organization and substantial downwind propagation (faster forward motion) of the snow squalls - something absent on 2 January 2012.

\section{Summary and discussion}

A composite study of snow squall environments was performed across Vermont and northern New York by systematically searching surface observations at KBTV, KMPV, and KMSS over 10 cool seasons. The ASOS observations indicated that moderate to heavy snow generally lasts $<30 \mathrm{~min}$ and typically is associated with falling temperatures and a pressure jump in the ensuing 1-2 $\mathrm{h}$, consistent with other types 

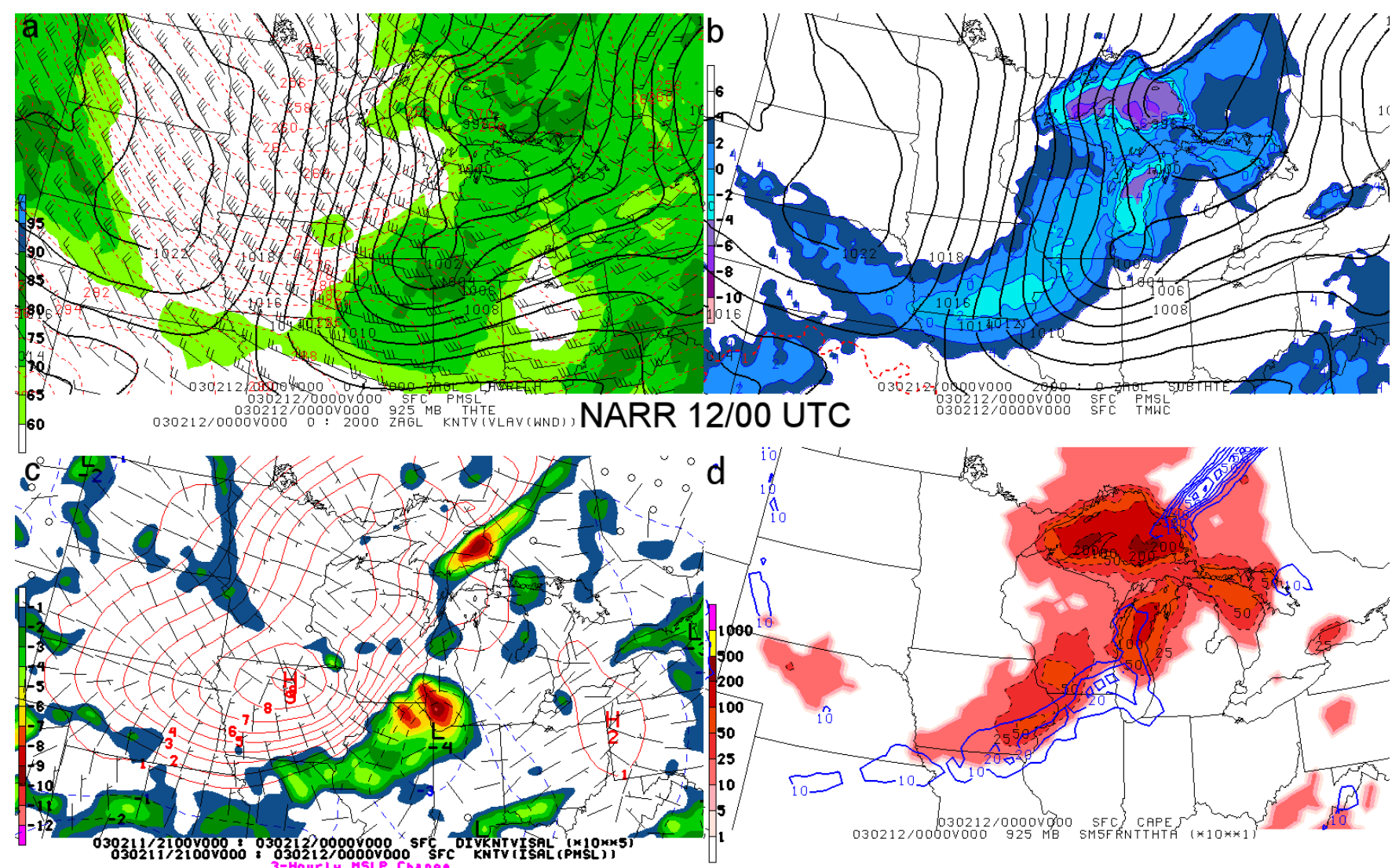

Figure 21. As in Fig. 17, except at 0000 UTC 12 February 2003.

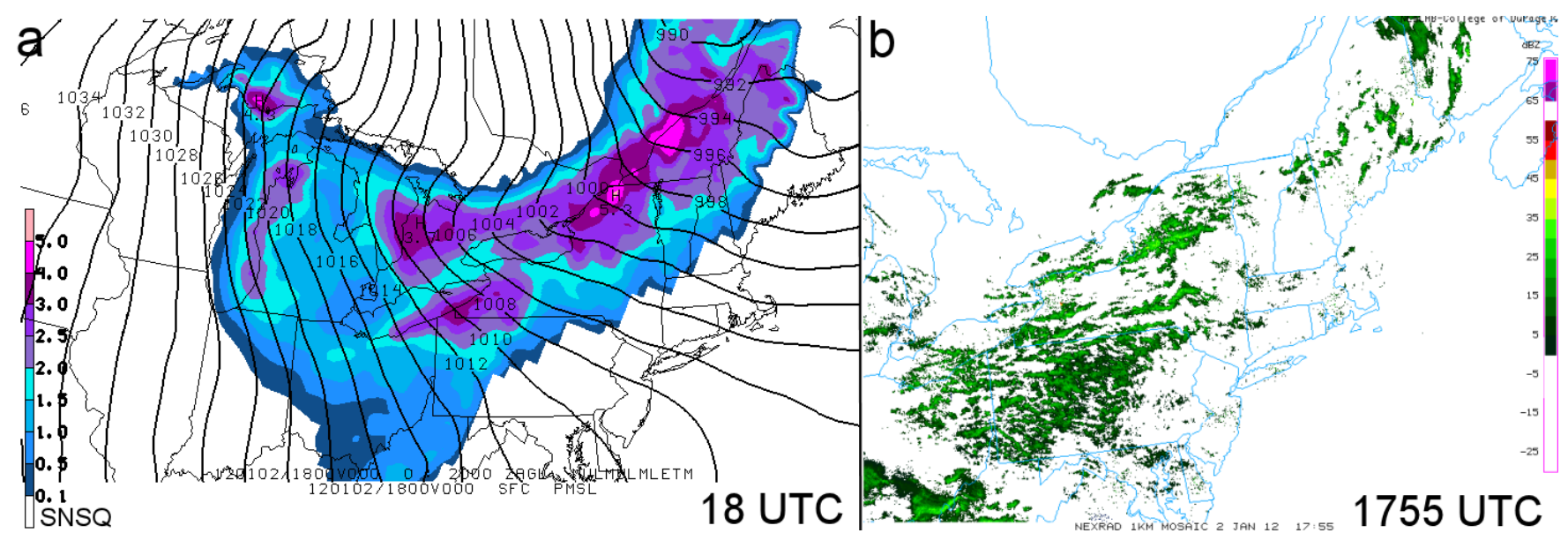

Figure 22. The NARR depiction of the (a) SNSQ (color filled, non-dimensional) plotted with sea-level pressure (black lines, every $2 \mathrm{hPa}$ ) at 18 UTC 2 January 2012 and (b) the mosaic composite reflectivity (dBZ) at 1755 UTC 2 January 2012.

of squall lines. The snow squalls often occurred along cold fronts and with intense isallobaric gradients-a function of the upscale forcing that often accompanies these MCSs. The associated downstream-directed isallobaric wind component and associated convergence drives system propagation (increasing the for- ward rate of motion), whereas evaporative effects and resultant surface-based cold pools are more likely to drive forward-propagation in warm-season squall lines. The synoptic environments were characterized by deep-layer cyclonic flow with a cold front approaching from the northwest (in the mean). All 36 

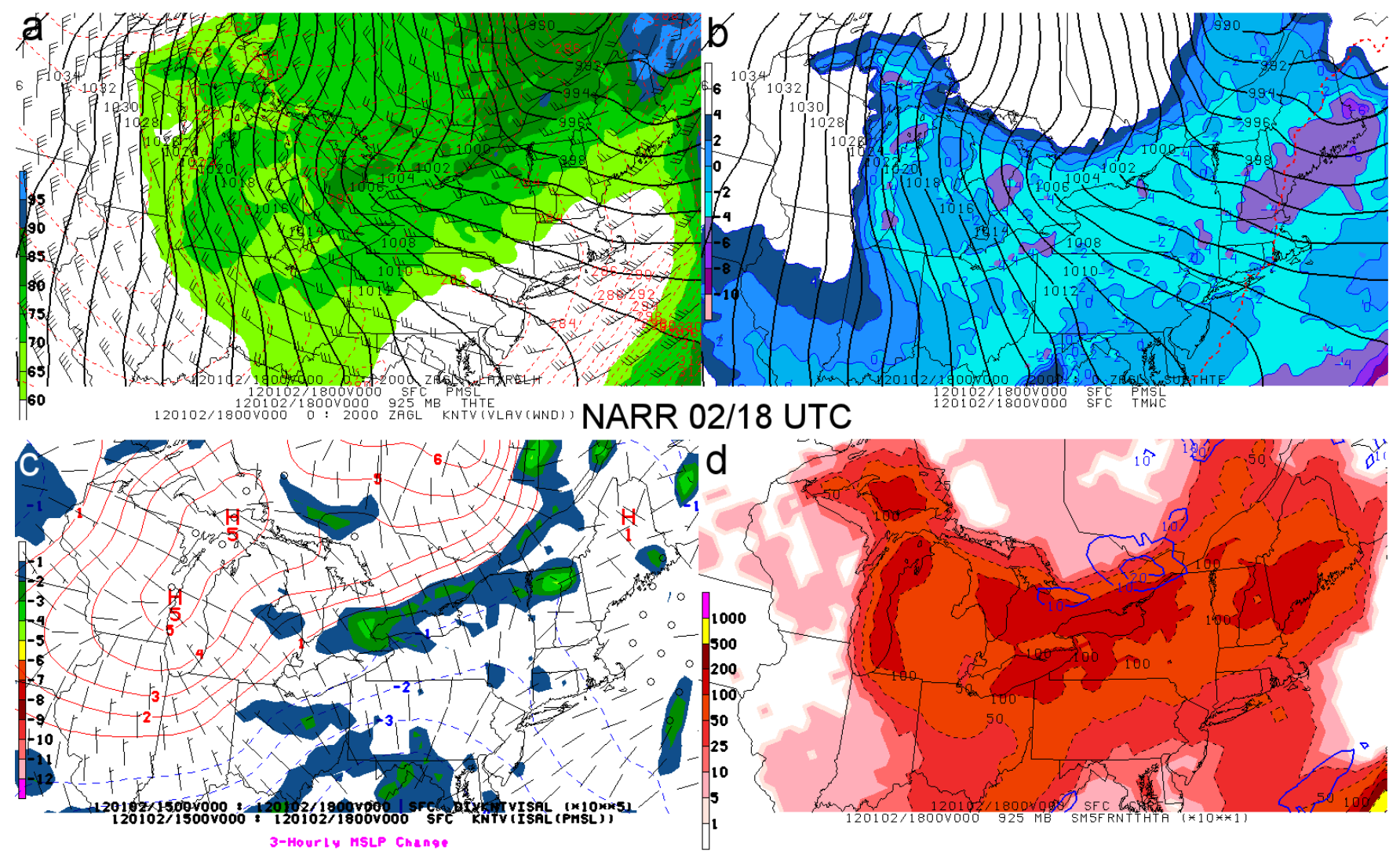

Figure 23. As in Fig. 17, except for 1800 UTC 2 January 2012.

snow squall events occurred on the cyclonic shear side of the maximum mid- to upper-tropospheric winds.

A comparison of the snow squall events with a control sample from the winter of 2005-06 shows that snow squalls occur in atypical wintertime environments with the presence of potential instability and modest surface-based CAPE (generally $<100 \mathrm{~J} \mathrm{~kg}^{-1}$ ). Surface-based instability and $0-2-\mathrm{km} \mathrm{RH}$ and wind can be effective in identifying favorable environments when combined with basic sea-level pressure and temperature data. The SNSQ was developed to highlight favored kinematic and thermodynamic environments for snow squalls. The collocation of positive SNSQ values with the leading edge of the strongest isallobaric gradient and low-level frontogenetic forcing was useful for finding linearly organized snow squalls near cold fronts producing surface visibilities $\leq 0.8 \mathrm{~km}(0.5$ $\mathrm{mi}$ ), as demonstrated in the included case studies and an analysis of POD and FAR (Fig. 16).

Snow squalls can range from being a nuisance to a serious transportation hazard, and the small amounts of snowfall typically involved do not lend themselves to heightened situational awareness of the forecaster or of the general public. In terms of the meteorology, dis- plays of instability should be appropriately scaled for wintertime situations (e.g., CAPE contours and associated color tables highlighting values of $10-100 \mathrm{~J} \mathrm{~kg}^{-1}$, not 100-1000 $\mathrm{J} \mathrm{kg}^{-1}$ ). The advocated 4-panel displays and SNSQ also should aid in diagnosing favorable snow squall environments. Antecedent weather and (warm) temperature conditions can reduce or eliminate melting and anti-skid agents from roadways. Rapidly falling temperatures after squall passage-especially if the road surfaces were initially above freezing - can cause flash freezing, quickly producing icy road conditions contributing to crashes and road closures. Meteorological and non-meteorological factors both must be diagnosed to anticipate the most severe transportation impacts (e.g., timing of squall with traffic volume).

Snowfall accumulations in squalls were typically around $2.5 \mathrm{~cm}$ (1 in), which fall short of NWS advisory and warning criteria across the northern United States, complicating how forecast offices should best disseminate and communicate the associated threat to transportation. Traditionally, the Emergency Alert System (EAS) has been leveraged to convey lifethreatening weather. While there may be some benefit 
to an NWS snow squall watch or warning product (as are issued by Environment Canada), short-fused warnings, in particular, result in a reactive mindset that may not be particularly beneficial unless the lead time exceeds that typically associated with other types of convective warnings. IDSS implies targeted information via one-on-one briefings to allow for a proactive and strategic mindset, and one that in this application would allow for hazard mitigation through pretreatment of road surfaces.

NWS forecast offices have increased their efforts to mitigate the effects of short-fused HISA events by partnering with emergency management and local public works departments to provide IDSS. In 2004, WFO State College, Pennsylvania, began an experimental partner project with the Pennsylvania Department of Transportation (PENNDOT) and the Pennsylvania State Police (PSP) to reduce the severe impact of HISA events along the I- 80 corridor in central Pennsylvania. This stretch of I-80 has a history of devastating multi-vehicle accidents during snow squalls (including Loganton, Pennsylvania, in 2001 and Milesburg, Pennsylvania, in 2004; Table 1)-resulting in many deaths and injuries and millions of dollars of economic loss. The Loganton, Pennsylvania, pileup in December 2001 that left 8 dead and 45 injured was a primary motivating factor behind this partnership, while another (the Milesburg, Pennsylvania, pileups of January 2004) served to promote greater awareness of the problem and the urgent need for agencies to work together with WFO State College to prevent future recurrences.

As part of the partnership, a snow squall notification plan was designed to aid mitigation activities by PENNDOT and PSP. The plan includes pretreatment of roads, and PENNDOT vehicles and State Police cruisers running their lights to slow the stream of automobile and truck traffic headed into intense snow squalls. In the years since the I-80 experimental notification project's implementation, no significant HISA incidents have occurred on this stretch of I-80 that crosses central Pennsylvania. This can be attributed, at least in part, to the notification plan and cooperation between WFO State College with PENNDOT and PSP. In contrast, severe HISA impacts have continued to occur outside of the experimental notification area. While phone and e-mail notification procedures and issuance of Special Weather Statements have been effective in reducing HISA impacts on I-80 in Pennsylvania, a more visible, efficient, and automated method of disseminating this information is needed. The pros- pect of improved snow squall forecasting with tailored IDSS should help minimize the severe transportation impacts posed by snow squalls. An integrated approach leveraging geographic information systems, social media, variable-message Intelligent Transportation System signs along roadways, and possibly EAS activation could all better address the non-meteorological and human decision-making factors important to mitigating negative travel impacts associated with snow squalls.

Improvement in the scientific and communicative accuracy of snow squall forecasts would be of value to the general public. A formal cost-loss ratio analysis (Murphy and Ehrendorfer 1987; Roebber and Bosart 1996) is beyond the scope of this work, but those interested in snow squalls as an interdisciplinary problem might consider the cost associated with treating a certain amount of state or interstate highway versus the cost involved to law enforcement and emergency personnel in responding to multiple accidents in the absence of such actions. The documented loss of life that has accompanied some of these situations alone necessitates formal notification plans between operational forecasters and federal, state, and local agencies to minimize such tragedies. A measurable and desired outcome of improved snow squall forecasts and development of notification plans would be the prospect of decreased highway crashes and pileups in association with such systems.

Acknowledgments. The authors thank Paul Sisson for his insights and support of this project. The authors also are grateful to John Goff, Rich Grumm, Brian Miretzky, Andy Nash, David Nicosia, and Jeff Waldstreicher for their helpful reviews and suggestions. Formal reviews by Roy Rasmussen and one anonymous reviewer further improved the paper. The NARR composite images were provided by the NOAA/ESRL Physical Sciences Division from their website (www.esrl.noaa.gov/psd/). WSR-88D mosaic composite reflectivity images were generated by the College of DuPage, and acquired from the Mesoscale and Microscale Meteorology Division of NCAR through their online archive (locust.mmm.ucar.edu/). The views expressed in this paper are those of the authors and do not necessarily reflect those of NOAA or the NWS.

\section{REFERENCES}

Bryan, G. H., and J. M. Fritsch, 2000: Moist absolute instability: The sixth static stability state. Bull. Amer. Meteor. Soc., 81, 1207-1230, CrossRef. 
Burke, P. C., and D. M. Schultz, 2004: A 4-yr climatology of cold-season bow echoes over the continental United States. Wea. Forecasting, 19, 1061-1074, CrossRef.

Cobb, D. K., Jr., and J. S. Waldstreicher, 2005: A simple physically based snowfall algorithm. Preprints, 21st Conf. on Weather Analysis and Forecasting/17th Conf. on Numerical Weather Prediction, Washington, D. C., Amer. Meteor. Soc., 2A.2. [Available online at ams.confex.com/ams/WAFNWP34BC/techprogram/ paper 94815.htm.]

Corfidi, S. F., S. J. Corfidi, D. A. Imy, and A. L. Logan, 2006: A preliminary study of severe wind-producing MCSs in environments of limited moisture. Wea. Forecasting, 21, 715-734, CrossRef.

desJardins, M. L., K. F. Brill, and S. S. Schotz, 1991: Use of GEMPAK on UNIX workstations. Preprints, Seventh Int. Conf. On Interactive Information and Processing Systems for Meteorology, Oceanography, and Hydrology, New Orleans, LA, Amer. Meteor. Soc., 449-453.

DeVoir, G., 2004: High impact sub-advisory snow events: The need to effectively communicate the threat of short duration high intensity snowfall. Preprints, 20th Conf. on Weather Analysis and Forecasting/16th Conf. on Numerical Weather Prediction, Seattle, WA, Amer. Meteor. Soc., 10.2. [Available online at ams.confex. com/ams/84Annual/techprogram/ paper_68261.htm.] , and D. Ondrejik, 2008: NWS expands efforts to mitigate effects of high impact sub-advisory snowfall. NWS Aware, 2, 15-16. [Available online at www.nws.noaa.gov/os/Aware/pdfs/08spring-aware.pdf.]

Doswell, C. A., III, 1987: The distinction between largescale and mesoscale contribution to severe convection: A case study example. Wea. Forecasting, 2, 3-16, CrossRef.

, and D. M. Schultz, 2006: On the use of indices and parameters in forecasting severe storms. Electronic $J$. Severe Storms Meteor., 1 (3), 1-22. [Available online at www.ejssm.org/ojs/index.php/ejssm/article/view/11/10.]

Eisenberg, D., and K. E. Warner, 2005: Effects of snowfalls on motor vehicle collisions, injuries, and fatalities. Amer. J. Public Health, 95, 120-124, CrossRef.

Evans, J. S., and C. A. Doswell III, 2001: Examination of derecho environments using proximity soundings. Wea. Forecasting, 16, 329-342, CrossRef.

Lundstedt, W., 1993: A method to forecast wintertime instability and non-lake effect snow squalls across northern New England. NOAA/NWS Eastern Region Tech. Attach. 93-11A, 7 pp. [Available online at www.erh.noaa.gov/er/hq/ssd/erps/ta/ta93-11a.1.pdf.]

Mahoney, E. A., and T. A. Niziol, 1997: BUFKIT: A software application toolkit for predicting lake-effect snow. Preprints, 13th Intl. Conf. on Interactive Information and Processing Systems for Meteorology, Oceanography, and Hydrology. Long Beach, CA, Amer. Meteor. Soc., 388-391.
Mesinger, F., and Coauthors, 2006: North American Regional Reanalysis. Bull. Amer. Meteor. Soc., 87, 343-360, CrossRef.

Milrad, S. M., J. R. Gyakum, E. H. Atallah, and J. F. Smith, 2011: A diagnostic examination of the eastern Ontario and western Quebec wintertime convection event of 28 January 2010. Wea. Forecasting, 26, 301-318, CrossRef.

Murphy A. H., and M. Ehrendorfer, 1987: On the relationship between the accuracy and value of forecasts in the cost-loss ratio situation. Wea. Forecasting, 2, 243-251, CrossRef.

NWS, cited 2013: Weather Ready Nation Roadmap. NOAA/NWS, Washington, D. C., 81 pp. [Available online at www.nws.noaa.gov/com/weatherreadynation/ files/nws_wrn_roadmap_final_april17.pdf.]

OFCM, 2005: Federal Meteorological Handbook No. 1: Surface weather observations and reports. FCM-H12005, U. S. Department of Commerce/National Oceanic and Atmospheric Administration, Office of the Federal Coordinator for Meteorological Services and Supporting Research, Washington, D. C., 104 pp. [Available online at www.ofcm.gov/fmh-1/pdf/FMH1.pdf.]

Orville, R. E., 2008: Development of the National Lightning Detection Network. Bull. Amer. Meteor. Soc., 89, 180190, CrossRef.

Pettegrew, B. P., P. S. Market, R. A. Wolf, R. L. Holle, and N. W. S. Demetriades, 2009: A case study of severe winter convection in the Midwest. Wea. Forecasting, 24, 121-139, CrossRef.

Rasmussen, R. M., J. Vivekanandan, J. Cole, B. Myers, and C. Masters, 1999: The estimation of snowfall rate using visibility. J. Appl. Meteor., 38, 1542-1563, CrossRef.

Roebber, P. J., and L. F. Bosart, 1996: The complex relationship between forecast skill and forecast value: A real-world analysis. Wea. Forecasting, 11, 544-559, CrossRef.

Thompson, R. L, R. Edwards, J. A. Hart, K. L. Elmore, and P. Markowski, 2003: Close proximity soundings within supercell environments obtained from the Rapid Update Cycle. Wea. Forecasting, 18, 1243-1261 CrossRef. , and C. M. Mead, 2004: An update to the supercell composite and significant tornado parameters. Preprints, 22nd Conf. Severe Local Storms, Hyannis MA, Amer. Meteor. Soc., P8.1. [Available online at ams.confex.com/ams/pdfpapers/82100.pdf.]

van den Broeke, M. S., D. M. Schultz, R. H. Johns, J. S. Evans, and J. E. Hales, 2005: Cloud-to-ground lightning production in strongly forced, low-instability convective lines associated with damaging wind. Wea. Forecasting, 20, 517-530, CrossRef. 